\title{
ทิศทางความเค้นหลัก: การวิเคราะห์
}

\section{เชิงจุดและเชิงสนามผ่านปัญหาใน}

ทฤษฎีสภาพยืดหยุ่น

พิเชษฐ์ พินิจ

ภาควิชาครุศาสตร์เครื่องกล คณะครุศาสตร์อุตสาหกรรมและเทคโนโลยี

มหาวิทยาลัยเทคในโลยีพระจอมเกล้าธนบุรี กรุงเทพฯ ประเทศไทย 10140

E-mail: pichet.pin@kmutt.ac.th

\section{บทคัดย่อ}

ตามประสบการณ์ของผู้เขียนพบว่า การเรียนการสอนในรายวิชากลศาสตร์วัสดุมักจะเน้นเฉพาะการคำนวณหา ทิศทางความเค้นหลักเชิงตัวเลข แต่มิได้มีการขยายความเชิงกายภาพให้ผู้เรียนเกิดความเข้าใจเชิงลึกใน ความสัมพันธ์ระหว่างค่าทิศทางกับค่าความเค้นหลักทั้งๆ ที่ค่าทิศทางเป็นปัจจัยหนึ่งที่มีความสำคัญในการ วิเคราะห์ความเค้น เพื่อเป็นการเติมเต็มช่องว่างดังกล่าว บทความฉบับนี้อธิบายวิธีการคำนวณหาทิศทางความ เค้นหลักโดยอาศัยวิธีการ 3 วิธี คือ สมการแปลงความเค้น วงกลมมอร์และจุดขั้ว และค่าเจาะจงและเวกเตอร์ เจาะจง ผ่านปัญหาระนาบในทฤษฎีสภาพยืดหยุ่น ผลลัพธ์การคำนวณจะแสดงออกมาทั้งในลักษณะเชิงจุดและ เชิงสนาม สิ่งที่ได้กล่าวในบทความนี้จะช่วยเสริมสร้างความเข้าใจเชิงลึกให้แก่ผู้เรียน ซึ่งในท้ายที่สุดผู้เขียน คาดหวังว่าผู้เรียนจะสามารถนำความรู้ไปใช้แก้ปัญหาหรือแปลความหมายเชิงกายภาพของปัญหาอื่นใดได้

\section{คำสืบค้น}

ทฤษฎีสภาพยืดหยุ่น ทิศทางความเค้นหลัก วงกลมมอร์และจุดขั้ว ค่าเจาะจงและเวกเตอร์เจาะจง สมการแปลง ความเค้น 


\title{
Directions of Principal Stresses: Point-wise ANd Full-Field Analyses Through a Problem in THEORY OF ELASTICITY
}

\section{Pichet Pinit}

\author{
Department of Mechanical Technology Education \\ Faculty of Industrial Education and Technology \\ King Mongkut's University of Technology Thonburi \\ Bangkok, Thailand 10140 \\ E-mail: pichet.pin@kmutt.ac.th
}

\section{ABSTRACT}

As far as concerned with author's experiences, most of teaching and learning processes in Mechanics of Materials emphasize only a numerical calculation of directions of principal stresses but lack an in-depth explanation to students about the relation between them and their principal stresses, in spite of their importance in stress analysis. To fill the gap, this paper describes a deep analysis of the directions of principal stresses using three different methods: equation of stress transformation, Mohr's circle and pole, and Eigen value and Eigen vector. These methods are applied on the basis of point-wise and whole-field representations to a two dimensional problem in Theory of Elasticity. The contents could enhance students' understanding with the hope that the students could apply the knowledge gained to solve or to interpret those related problems in hand.

\section{KEYWORDS}

theory of elasticity, directions of principal stresses, Mohr' circle and pole, eigen value and eigen vector, equation of stress transformation 


\section{I. บทนำ}

รายวิชากลศาสตร์วัสดุ (Mechanics of Materials) เป็นรายวิชาเบื้องต้นที่ศึกษาเกี่ยวกับการเปลี่ยนรูปของวัสดุ ภายใต้การกระทำของภาระภายนอก ผลของภาระภายนอกทำให้เกิดความเค้นขึ้นภายในวัสดุและความเค้นนี้ เป็นปริมาณภายในที่ไม่สามารถมองเห็นได้ด้วยตาเปล่า อย่างไรก็ดีความเค้นหรือสนามความเค้นสามารถ มองเห็นได้หากใช้วิธีโฟโตอิลาสติกซิตี ในทางทฤษฎี ความเค้นถือเป็นปริมาณทางฟิสิกส์ที่เรียกว่า เทนเซอร์ (tensor) มีอันดับเท่ากับ 2 และต้องการองค์ประกอบทั้งหมด 9 องค์ประกอบในการอธิบายให้มีความหมาย สมบูรณ์ในระบบสามมิติ

ความเค้นเป็นปริมาณที่มีทั้งขนาดและทิศทาง ขนาดของความเค้นบ่งบอกถึงความหนาแน่นของแรงภายในบน พื้นที่หน้าตัดหนึ่งๆ ในขณะที่ทิศทางของความเค้นจะแสดงแนวหรือวิถีที่ความเค้นนั้นกระทำ องค์ประกอบทั้ง สองนี้ช่วยให้เราทราบว่า บริเวณใดที่จะเกิดความเสียหายและความเสียหายนี้จะเกิดขึ้นในทิศทางใด สำหรับ ความเสียหายนั้นมักจะมีทิศทางตั้งฉากกับความเค้นค่าสูงสุด [1] จากการสังเกตของผู้เขียนหลายครั้งในคราวที่ มีการเรียนการสอนในรายวิชาการออกแบบชิ้นส่วนเครื่องจักรกล (โดยการเรียนในเบื้องต้นเป็นการทบทวน ความรู้เดิมที่ผู้เรียนได้เรียนมาแล้วในรายวิชากลศาสตร์วัสดุ) พบว่า ผู้เรียนมีความเข้าใจเป็นอย่างดีเกี่ยวกับ ขนาดของความเค้นหลัก แต่ผู้เรียนไม่สามารถให้คำอธิบายเชิงลึกเกี่ยวกับทิศทางความเค้นหลักได้ กล่าวคือ ผู้เรียนไม่สามารถอธิบายความสัมพันธ์ระหว่างทิศทางความเค้นหลักกับลักษณะความเสียหายที่เกิดขึ้นในวัสดุ ได้ ผู้เขียนได้พยายามค้นหาสาเหตุเกี่ยวกับปัญหาข้างต้น ซึ่งสามารถสรุปประเด็นได้ดังนี้ เนื่องจากขนาดของ ความเค้นหลักเป็นปริมาณสเกลาร์ ดังนั้น การที่ผู้เรียนจะเข้าใจเกี่ยวกับขนาดความเค้นจึงเป็นเรื่องที่ไม่ยาก เกินไป สาเหตุที่เป็นเช่นนี้ก็เพราะว่า ในชีวิตประจำวันเรามักจะใช้ปริมาณสเกลาร์สื่อสารกันเป็นส่วนใหญ่ อย่างไรก็ตาม การรวมกันระหว่างทิศทางกับขนาดความเค้นหลักเป็นผลให้ลักษณะของสิ่งที่ผู้เรียนจะต้องทำ ความเข้าใจเปลี่ยนจากรูปธรรมไปเป็นนามธรรม ซึ่งในท้ายที่สุดส่งผลให้ผู้เรียนขาดความเข้าใจ

ผู้เขียนได้เคยตั้งคำถามกับผู้เรียนโดยให้ผู้เรียนจินตนาการถึงการทุบกระบอกข้าวหลามที่ยังไม่ได้ปอกผิวแข็ง ออก โดยที่รายละเอียดต่าง ๆ แสดงในตารางที่ 1

\section{ตารางที่ 1}

เงื่อนไขและคำถาม เกี่ยวกับกระบอกข้าว หลาม โดยที่คำถามเป็น ของผู้เขียนและคำตอบ เป็นของผู้เรียน

\begin{tabular}{|c|c|c|c|}
\hline \multirow{2}{*}{$\begin{array}{l}\text { เงื่อนไข: } \\
\text { คำถาม: }\end{array}$} & \multicolumn{3}{|c|}{ หากเราใช้มีดหรือขวานฟันไปยังกระบอกข้าวหลามตามแนวยาวและ/หรือตามแนวขวาง } \\
\hline & $\begin{array}{l}\text { กระบอกข้าวหลามจะเกิดความเสียหาย } \\
\text { หรือแตกในแนวใด? }\end{array}$ & คำตอบ: & $\begin{array}{l}\text { กระบอกข้าวหลามจะแตกตามแนวยาว } \\
\text { หรือตามแนวแกน }\end{array}$ \\
\hline คำถาม: & เหตุใดจึงเป็นเช่นนั้น? & คำตอบ: & $\begin{array}{l}\text { ในทางทฤษฎีนั้น ความเค้นในแนวเส้นรอ } \\
\text { บวง (hoop stress) จะมีค่ามากกว่าความ } \\
\text { เค้นในแนวแกน (axial stress) } 2 \text { เท่า }\end{array}$ \\
\hline คำถาม: & $\begin{array}{l}\text { หากสัดส่วนของความเค้นมีค่า } 1.5 \text { เท่า } \\
\text { หรือ } 2.5 \text { เท่า แล้ว กระบอกข้าวหลามจะ } \\
\text { เกิดความเสียหายหรือแตกในแนวใด? }\end{array}$ & คำตอบ: & $\begin{array}{l}\text { ??? หรือ กระบอกข้าวหลามจะแตกตาม } \\
\text { แนวยาวหรือตามแนวแกน (สำหรับผู้เรียน } \\
\text { บางคน) }\end{array}$ \\
\hline
\end{tabular}

คำถามข้างต้นมีนัยสำคัญซ่อนอยู่ กล่าวคือ การที่กระบอกข้าวหลามจะแตกหรือไม่นั้น มิได้ขึ้นอยู่กับจำนวนเท่า ของอัตราส่วนระหว่างความเค้นในเส้นรอบวงต่อความเค้นในแนวแกน แต่จะขึ้นอยู่กับอัตราส่วนระหว่างความ ต้านแรงครากของวัสดุ (yield strength) ต่อความเค้นที่เกิดขึ้น หลักในการออกแบบก็คือ การนำความเค้นที่มี ค่าสูงสุด (maximum stress) ไปเปรียบเทียบกับความต้านแรงคราก ทั้งนี้รูปแบบการเปรียบเทียบขึ้นอยู่กับ 
ทฤษฎีความเสียหายที่เลือกใช้ เนื่องจากความเค้นในแนวเส้นรอบวงมีค่ามากกว่าความเค้นในแนวแกน ดังนั้น ความเค้นที่ถูกนำไปเปรียบเทียบก็คือ ความเค้นในแนวเส้นรอบวงนั่นเอง

หากความเค้นค่าสูงสุดมีค่ามากกว่าความต้านแรงครากของวัสดุก็จะทำให้เกิดความเสียหายขึ้น คำถามจึงมีอยู่ ว่า จะเกิดความเสียหายอย่างไร? (ตารางที่ 1 ) คำตอบก็คือ ความเสียหายหรือการแตกร้าวจะเกิดขึ้นในแนวหรือ ทิศทางที่ตั้งฉากกับทิศทางความเค้นหลักดังที่ได้กล่าวแล้วข้างต้น เราจะเห็นได้ว่า ทิศทางความเค้นหลักเป็น ปัจจัยสำคัญอันหนึ่งในการอธิบายถึงลักษณะความเสียหายที่จะเกิดขึ้น เพื่อให้เกิดความเข้าใจเชิงลึกแก่ผู้เรียน บทความนี้นำเสนอวิธีการคำนวณหาทิศทางความเค้นหลักแบบเชิงจุดและเชิงสนามผ่านปัญหาแผ่นจานกลม รับแรงเข้มกดในแนวเส้นผ่านศูนย์กลาง (a circular disk subjected a diametral compression) ซึ่งปัญหานี้มี ผลเฉลยแม่นตรงที่พิสูจน์ทราบแล้วโดยทฤษฎีสภาพยืดหยุ่น

\section{II. วิธีการคำนวณหาความเค้นหลักและทิศทาง}

\section{1 สมการแปลงความเค้นในพจน์ขององค์ประกอบความเค้นสมการแปลง ความเค้นในพจน์ของความเค้นหลัก}

สำหรับปัญหาความเค้นระนาบ (plane problem) ความเค้น ณ จุดหนึ่ง ๆ ที่มุมใดๆ สามารถคำนวณหา ได้จากสมการแปลงความเค้น [2]

$$
\begin{aligned}
& \sigma_{x^{\prime} x^{\prime}}=\frac{1}{2}\left(\sigma_{x x}+\sigma_{y y}\right)+\frac{1}{2}\left(\sigma_{x x}-\sigma_{y y}\right) \cos 2 \theta+\tau_{x y} \sin 2 \theta \\
& \sigma_{y^{\prime} y^{\prime}}=\frac{1}{2}\left(\sigma_{x x}+\sigma_{y y}\right)-\frac{1}{2}\left(\sigma_{x x}-\sigma_{y y}\right) \cos 2 \theta-\tau_{x y} \\
& \tau_{x^{\prime} y^{\prime}}=-\frac{1}{2}\left(\sigma_{x x}-\sigma_{y y}\right) \sin 2 \theta+\tau_{x y} \cos 2 \theta
\end{aligned}
$$

โดยที่ มุม $\theta$ คือ มุมระหว่างแกนพิกัด $x-y$ และ $x^{\prime}-y^{\prime}$ ซึ่งวัดในทิศทางทวนเข็มนาพิกา (รูปที่ 1)

ความเค้นหลักและทิศทางความเค้นหลักสามารถคำนวณหาได้จากสมการ

$$
\sigma_{1,2}=\frac{\sigma_{x x}+\sigma_{y y}}{2} \pm \sqrt{\left(\frac{\sigma_{x x}-\sigma_{y y}}{2}\right)^{2}+\tau_{x y}^{2}}
$$

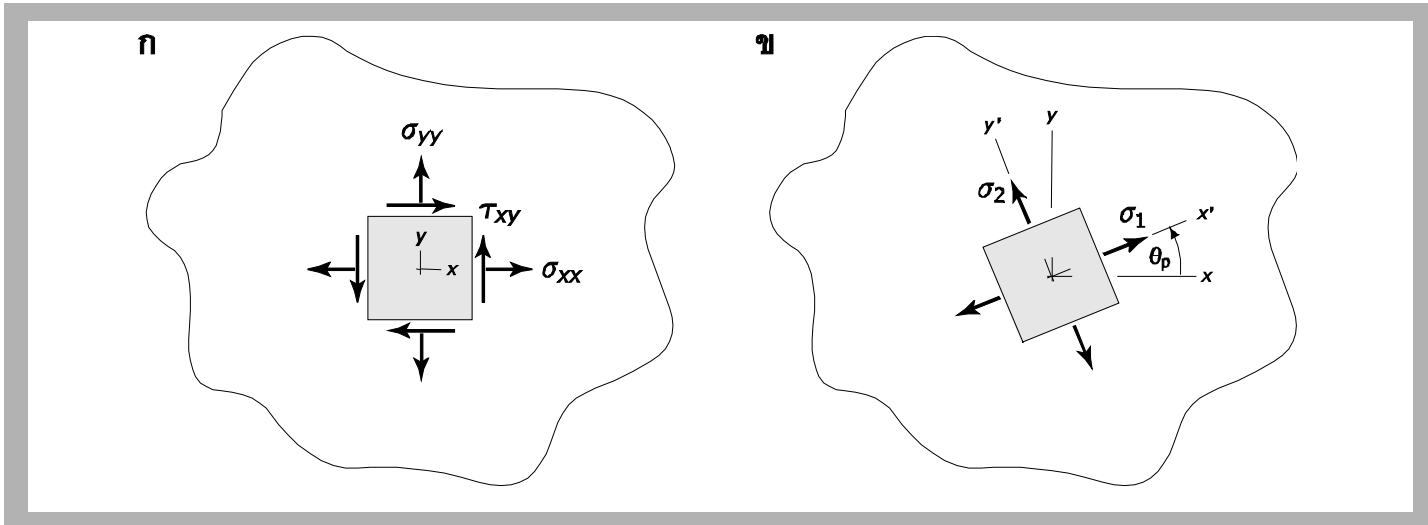

รูปที่ 1

(ก) เอลิเมนต์ความเค้นทั่วไป ในระบบพิกัดอ้างอิง $x-y$ และ (ข) เอลิเมนต์ความเค้น หลักในแนวแกน $x^{\prime}-y^{\prime}$

และ

$$
\tan 2 \theta_{p}=\frac{2 \tau_{x y}}{\sigma_{x x}+\sigma_{y y}} \text { หรือ } \theta_{p}=\frac{1}{2} \arctan \left(\frac{2 \tau_{x y}}{\sigma_{x x}-\sigma_{y y}}\right)
$$


ตามลำดับ โดยที่ $\sigma_{1}$ และ $\sigma_{2}$ คือ ความเค้นหลัก $\sigma_{x x} \sigma_{y}$ และ $\tau_{x y}$ คือ องค์ประกอบความเค้นใน ระบบพิกัดคาร์ทีเซียนหรือระบบพิกัดฉาก และ $\theta_{p}$ คือ มุมที่แสดงทิศทางความเค้นหลัก ซึ่งวัดเทียบกับ แกนอ้างอิง $x$ ในทิศทางทวนเข็มนาฬิกา สำหรับตัวห้อย $p$ นั้นหมายถึง การใช้ค่าหลัก (principal values) ของฟังก์ชันแทนเจนต์ผกผันในย่าน $-90^{\circ}$ ถึง $+90^{\circ}$ ที่รวมค่า $0^{\circ}$ เข้าไว้ด้วยเท่านั้นทั้งนี้ เพราะว่า ฟังก์ชันแทนเจนต์เป็นฟังก์ชันคาบ (periodic function) จากความสัมพันธ์ $\tan 2 \theta_{p}=\tan \left(2 \theta_{p} \pm 180^{\circ}\right)$ ฟังก์ชันแทนเจนต์ผกผันในสมการ (3) จะให้ค่ามุม $\theta$ ออกมาสองค่าที่ ห่างกันเท่ากับ $90^{\circ}$ (ความเค้นหลักทั้งสองมีทิศทางตั้งฉากซึ่งกันและกัน) ด้วยเหตุนี้ การใช้สมการ (3) คำนวณหาทิศทางความเค้นหลักเพียงสมการเดียวจึงไม่สามารถระบุได้ว่า มุม $\theta_{p}$ ค่าใดจะแสดงทิศทาง ความเค้นหลัก $\sigma_{1}$ หรือ $\sigma_{2}[1]$

เนื่องจากว่าอาร์กิวเมนต์ของฟังก์ชันแทนเจนต์ในสมการ (3) อยู่ในรูปของ $2 \theta_{p}$ ดังนั้น มุม $\theta_{p}$ จึงมีค่า อยู่ในย่าน $-45^{\circ}$ ถึง $+45^{\circ}$ เท่านั้น ซึ่งในทางกายภาพแล้ว มุม $\theta_{p}$ จะต้องมีค่าอยู่ในย่าน $-90^{\circ}$ ถึง $+90^{\circ}$ ปรากฏการณ์นี้ทำให้เราเรียกผลลัพธ์ที่ได้จากสมการ (3) ว่า 'ค่าเฟสซ่อนรูป' (wrapped phase) และค่ามุมทางกายภาพว่า 'ค่าเฟสเต็มรูป' (unwrapped phase) สำหรับการแก้ปัญหาดังกล่าวในทาง ปฏิบัตินั้น เราจะต้องหาวิธีการอื่นใดที่จะทำให้ได้ค่าเฟสเต็มรูปจากเฟสซ่อนรูป วิธีการที่กล่าวถึงนี้เป็นที่ รู้จักกันดีในชื่อของ 'การคืนรูปเฟส' (phase unwrapping) [3] ค่าเฟสซ่อนรูปทำให้เราไม่สามารถระบุได้ ว่ามุม $\theta_{p}$ ที่คำนวณได้จากสมการ (3) นั้น ค่าใดจะแสดงทิศทางความเค้นหลัก $\sigma_{1}$ หรือ $\sigma_{2}$ ที่ คำนวณได้จากสมการ (2) สำหรับตัวอย่างการคำนวณนั้นจะได้แสดงต่อไป คำว่า เฟสซ่อนรูป เฟสเต็ม รูป และการคืนรูปเฟส เป็นคำที่ผู้เขียนได้บัญญัติขึ้นใช้เองเนื่องจากยังไม่มีการบัญญัติคำเหล่านี้ใน ภาษาไทยอย่างเป็นทางการ สำหรับเนื้อหาเกี่ยวกับการคืนรูปเฟสนั้น ผู้เขียนจะไม่ขอกล่าวใน รายละเอียดเนื่องจากอยู่นอกเหนื่อวัตถุประสงค์ของบทความฉบับนี้

เราสามารถพิสูจน์ที่มาของสมการ (3) ได้โดยการกำหนดให้ $\tau_{x^{\prime} y^{\prime}}=0$ (ที่ระนาบหลักความเค้นเฉือนมี ค่าเท่ากับศูนย์) ซึ่งผลที่ได้แสดงให้เห็นว่า ณ จุดหนึ่ง ๆ ค่าความเค้นหลักและทิศทางจะมีอยู่เพียงชุด เดียวเท่านั้น หากพิจารณาจุดอื่นใดในอาณาบริเวณที่สนใจ เราก็จะได้ความเค้นหลักอีกชุดหนึ่งซึ่งมีค่า แตกต่างกันไปทั้งขนาดและทิศทาง การเปลี่ยนไปของทิศทางความเค้นนี้เองทำให้เกิดการไหลของความ เค้น [1]

สำหรับการคำนวณหาค่าทิศทางความเค้นหลักที่สอดคล้องกับค่าความเค้นหลักค่าใดค่าหนึ่งนั้น เรา สามารถทำได้ตามขั้นตอนดังนี้

1. คำนวณหาค่าความเค้นหลัก $\sigma_{1}$ และ $\sigma_{2}$ และทิศทางความเค้นหลัก $\theta_{p}$ โดยอาศัยสมการ (2) และ (3) ตามลำดับ

2. นำค่าทิศทางความเค้นหลัก $\theta_{p}$ ค่าใดค่าหนึ่ง (โดยปกติใช้ค่าแรก) ไปแทนลงในตัวแปร $\theta$ ที่ปรากฏอยู่ในสมการ $\sigma_{x^{\prime} y^{\prime}}$ ลำดับแรกของสมการ (1)

3. เปรียบเทียบค่า $\sigma_{x^{\prime} y^{\prime}}$ ที่คำนวณได้จากข้อ 2. กับค่าความเค้นหลัก $\sigma_{1}$ และ $\sigma_{2}$ ที่คำนวณ ได้จาก ข้อ 1 . 
หากค่าของ $\sigma_{x^{\prime} y^{\prime}}$ ตรงกับค่าความเค้นหลักค่าใด ทิศทางความเค้นหลัก $\theta_{p}$ ก็จะแสดงทิศทางของความ เค้นหลักค่านั้น ส่วนค่ามุมที่เหลือก็จะเป็นทิศทางของความเค้นหลักอีกค่าหนึ่ง

ผู้อ่านพึงสังเกตว่า หากเราแทนค่าทิศทางความเค้นหลัก $\theta_{p}$ ลงในมุม $\theta$ ที่ปรากฏอยู่ในสมการ $\sigma_{x^{\prime} y^{\prime}}$ ของสมการ (1) จะเป็นผลให้เกิดการสลับของทิศทางความเค้นหลัก ดังนั้น เพื่อให้ได้ผลลัพธ์ที่ถูกต้อง เรา จะต้องแทนลงในมุม $\theta$ ที่ปรากฏอยู่ในสมการ $\sigma_{x^{\prime} y^{\prime}}$ เท่านั้นเนื่องจาก $\theta$ เป็นมุมระหว่างแกน $x$ กับ $x^{\prime}$ (รูปที่ 1)

\section{2 สมการแปลงความเค้นในพจน์ของความเค้นหลัก}

หากเราทราบค่าความเค้นหลัก จากสมการ (2) ค่าความเค้นที่ตำแหน่งเชิงมุม $\theta$ ใด ๆ ก็สามารถ คำนวณหาได้จากสมการ

$$
\begin{aligned}
& \sigma_{x^{\prime} x^{\prime}}=\frac{1}{2}\left(\sigma_{1}+\sigma_{2}\right)+\frac{1}{2}\left(\sigma_{1}-\sigma_{2}\right) \cos 26 \\
& \sigma_{y^{\prime} y^{\prime}}=\frac{1}{2}\left(\sigma_{1}+\sigma_{2}\right)-\frac{1}{2}\left(\sigma_{1}-\sigma_{2}\right) \cos 26 \\
& \tau_{x^{\prime} y^{\prime}}=-\frac{1}{2}\left(\sigma_{1}+\sigma_{2}\right) \sin 2 \theta
\end{aligned}
$$

โดยที่ มุม $\theta$ คือ มุมระหว่างแกนพิกัด $\sigma_{1}-\sigma_{2}$ และ $x^{\prime}-y^{\prime}$ ซึ่งวัดในทิศทางทวนเข็มนาฬิกา ความสัมพันธ์ดังกล่าวสามารถทำความเข้าใจได้โดยพิจารณารูปที่ 1 โดยกำหนดให้แกนพิกัด $x-y$ เป็น $\sigma_{1}-\sigma_{2}$, แกนพิกัด $\sigma_{1}-\sigma_{2}$ เป็น $x^{\prime}-y^{\prime}$ และมุม $\theta_{p}$ เป็น $\theta$

สมการ (4) ถือเป็นหัวใจสำคัญในการศึกษาทางด้านโฟโตอิลาสติกซิตีโดยเฉพาะสมการความเค้นเฉือน ในลำดับสุดท้าย ทั้งนี้เพราะว่า องค์ประกอบความเค้นทั้งสามในระบบแกนอ้างอิง $x^{\prime}-y^{\prime}$ จะอยู่ในพจน์ ของผลรวมของความเค้นหลัก ผลต่างของความเค้นหลัก และทิศทางความเค้นหลัก ในสาขาโฟโตอิลา สติกซิตี ผลรวมของความเค้นหลัก $\left(\sigma_{1}+\sigma_{2}\right)$ มีชื่อเรียกว่า ไอโซพาชิก (isopachics) ผลต่างของ ความเค้นหลัก $\left(\sigma_{1}-\sigma_{2}\right)$ มีชื่อเรียกว่า ไอโซโครมาติก (isochromatics) และทิศทางความเค้นหลัก $\theta_{p}$ มีชื่อเรียกว่า ไอโซคลินิก (isoclinics) อาศัยข้อมูลไอโซโครมาติกและไอโซคลินิก เราสามารถ คำนวณหาค่าความเค้นเฉือน $\tau_{x y}$ ได้ [4], [5]

\section{3 โคไซน์แสดงทิศทางความเค้นหลัก: ค่าเจาะจงและเวกเตอร์เจาะจง}

เราสามารถคำนวณหาโคไซน์แสดงทิศทางของความเค้นหลักได้ โดยอาศัยสมการ [2]

$$
\begin{aligned}
& \left(\sigma_{x x}-\sigma_{p}\right) n_{x}+\tau_{x y} n_{y}=0 \\
& \tau_{x y} n_{x}+\left(\sigma_{y y}-\sigma_{p}\right) n_{y}=0
\end{aligned}
$$

และ

$$
n_{x}^{2}+n_{y}^{2}=1
$$

โดยที่ $\sigma_{p}(p=1,2)$ คือ ความเค้นหลัก และ $n_{x}$ และ $n_{y}$ คือ ค่าโคไซน์แสดงทิศทางของทิศทางความ เค้นหลักเทียบกับแกน $x$ และ แกน $y$ ตามลำดับ เนื่องจากปัญหาที่พิจารณาเป็นปัญหาความเค้นระนาบ 
หากกำหนดให้ทิศทางความเค้นหลักวัดเที่ยบกับแกนอ้างอิง $x$ เพียงแกนเดียวแล้ว เราก็จะได้ $n_{x}=\cos \theta_{p}$ และ $n_{y}=\sin \theta_{p}$ ซึ่งทำให้เราเขียนสมการ (5) และ (6) ได้ใหม่คือ

$$
\begin{aligned}
& \left(\sigma_{y y}+\sigma_{p}\right) \cos \theta_{p}+\tau_{x y} \sin \theta_{p}=0 \\
& \tau_{x y} \cos \theta_{p}+\left(\sigma_{y y}+\sigma_{p}\right) \sin \theta_{p}=0
\end{aligned}
$$

และ

$$
\cos ^{2} \theta_{p}+\sin ^{2} \theta_{p}=1
$$

สมการ (5) ถึง (8) แสดงให้เห็นว่า $\sigma_{p}$ คือ ค่าเจาะจง (Eigen value) และโคไซน์แสดงทิศทาง $n_{x}$ และ $n_{y}$ คือเวกเตอร์เจาะจง (Eigen vector) ที่สอดคล้องกันนั่นเอง

ด้วยสมการ $(7)$ และ $(8)$ เราจะได้ว่า

$$
\sin \theta_{p}=\sqrt{\frac{1}{1+\left(\frac{\sigma_{y y}-\sigma_{p}}{\tau_{x y}}\right)^{2}}}=\sqrt{\frac{\tau_{x y}^{2}}{\tau_{x y}^{2}+\left(\sigma_{y y}-\sigma_{p}\right)^{2}}}
$$

และ

$$
\cos \theta_{p}=-\left(\frac{\sigma_{y y-} \sigma_{p}}{\tau_{x y}}\right) \sin \theta_{p}
$$

ดังนั้น เราสามารถคำนวณหาทิศทางความเค้นหลักได้โดยความสัมพันธ์

$$
\theta_{p}=\arctan \left(\frac{\sin \theta_{p}}{\cos \theta_{p}}\right)
$$

สำหรับการระบุทิศทางความเค้นหลักที่สอดคล้องกับค่าความเค้นหลักนั้น เราสามารถทำได้ตามขั้นตอนดังนี้

1. คำนวณหาค่าความเค้นหลัก $\sigma_{1}$ และ $\sigma_{2}$ โดยอาศัยสมการ (2)

2. นำค่าความเค้นหลัก $\sigma_{1}$ หรือ $\sigma_{2}$ แทนลงไปที่ $\sigma_{p}$ ในสมการ (9) และ (10)

3. คำนวณหาค่าทิศทางความเค้นหลัก $\theta_{p}$ โดยสมการ (11)

ผู้อ่านพึงสังเกตความแตกต่างระหว่างผลลัพธ์ของสมการ (3) กับ (11) กล่าวคือ สมการ (3) จะทำให้ $-45^{\circ} \leq \theta_{p} \leq+45^{\circ}$ (เฟสซ่อนรูป) ขณะที่สมการ (11) จะให้ผลลัพธ์ $-90^{\circ} \leq \theta_{p} \leq+90^{\circ}$ (เฟสเต็มรูป) สำหรับความหมายของเฟสซ่อนรูปในเชิงรูปธรรมนั้น ผู้เขียนจะได้อธิบายให้เกิดความเข้าใจมากยิ่งขึ้นใน หัวข้อ III

\section{4 วงกลมมอร์}

วงกลมมอร์เป็นเครื่องมืออันหนึ่งที่แสดงความหมายของสมการ (1) ออกมาในเชิงรูปภาพ วงกลมมอร์ทำ ให้เราเข้าใจเกี่ยวกับการแปรเปลี่ยนค่าไปขององค์ประกอบความเค้นเมื่อมุม $\theta$ มีค่าแปรเปลี่ยนไป รูปที่ 2 แสดงภาพตัวอย่างของวงกลมมอร์ สำหรับการวาดวงกลมมอร์มีขั้นตอนดังนี้

1. กำหนดแกนพิกัด $\sigma$ และ $\tau$ โดยที่ $\sigma^{+}$ให้มีทิศทางไปทางขวา และ $\tau^{c \mathrm{CW}}$ (ความเค้น เฉือนในทิศทางทวนเข็มนาฬึกา) มีทิศทางลงด้านล่าง 
2. กำหนดจุดศูนย์กลางของวงกลมมอร์ (จุด $\mathrm{C}$ ) บนแกน $\sigma$ ที่ระยะห่างเท่ากับ $\frac{1}{2}\left(\sigma_{x x}+\sigma_{y y}\right)$ จากจุดกำเนิด (จุด O) ของแกนพิกัด $\sigma$ และ $\tau$

3. กำหนดจุด $\mathrm{A}\left(\sigma_{x x}, \tau_{x y}^{\mathrm{ccw}}\right)$ ลงบนระนาบ โดยค่าที่เลือกใช้ให้เป็นค่าองค์ประกอบความเค้น บนหน้าตัด $x^{+}$(ดูรูปเอลิเมนต์ความเค้น ในรูปที่ 2)

4. วาดวงกลมโดยใช้จุด $\mathrm{C}$ เป็นจุดศูนย์กลาง โดยที่วงกลมมีรัศมีเท่ากับระยะ $\overline{C A}$

5. ลากเส้น $\overline{A B}$ ผ่านจุดศูนย์กลาง $\mathrm{C}$ โดยที่จุด $\mathrm{B}$ ก็คือจุดที่มีค่าองค์ประกอบความเค้นบนหน้า ตัด $y^{+}$

พึงสังเกตว่า มุม $\theta$ บนวงกลมจะมีค่าเป็นสองเท่าของมุม $\theta$ บนเอลิเมนต์ความเค้น แต่วัดในทิศทาง ทวนเข็มนาฬิกาเช่นเดียวกัน

จากรูปที่ 2 รัศมีของวงกลม (ความเค้นเฉือนค่าสูงสุด) คือ

$$
\begin{gathered}
R=\overline{C A}=\overline{C B}=\tau_{\text {max }}=\sqrt{\left(\frac{\sigma_{x x}-\sigma_{y y}}{2}\right)^{2}+\tau_{x y}^{2}} \\
\sigma_{1,2}=O C \pm \tau_{\max }=\frac{\sigma_{x x}+\sigma_{y y} \pm \sqrt{\left(\frac{\sigma_{x x}-\sigma_{y y}}{2}\right)^{2}+\tau_{x y}^{2}}}{2}
\end{gathered}
$$

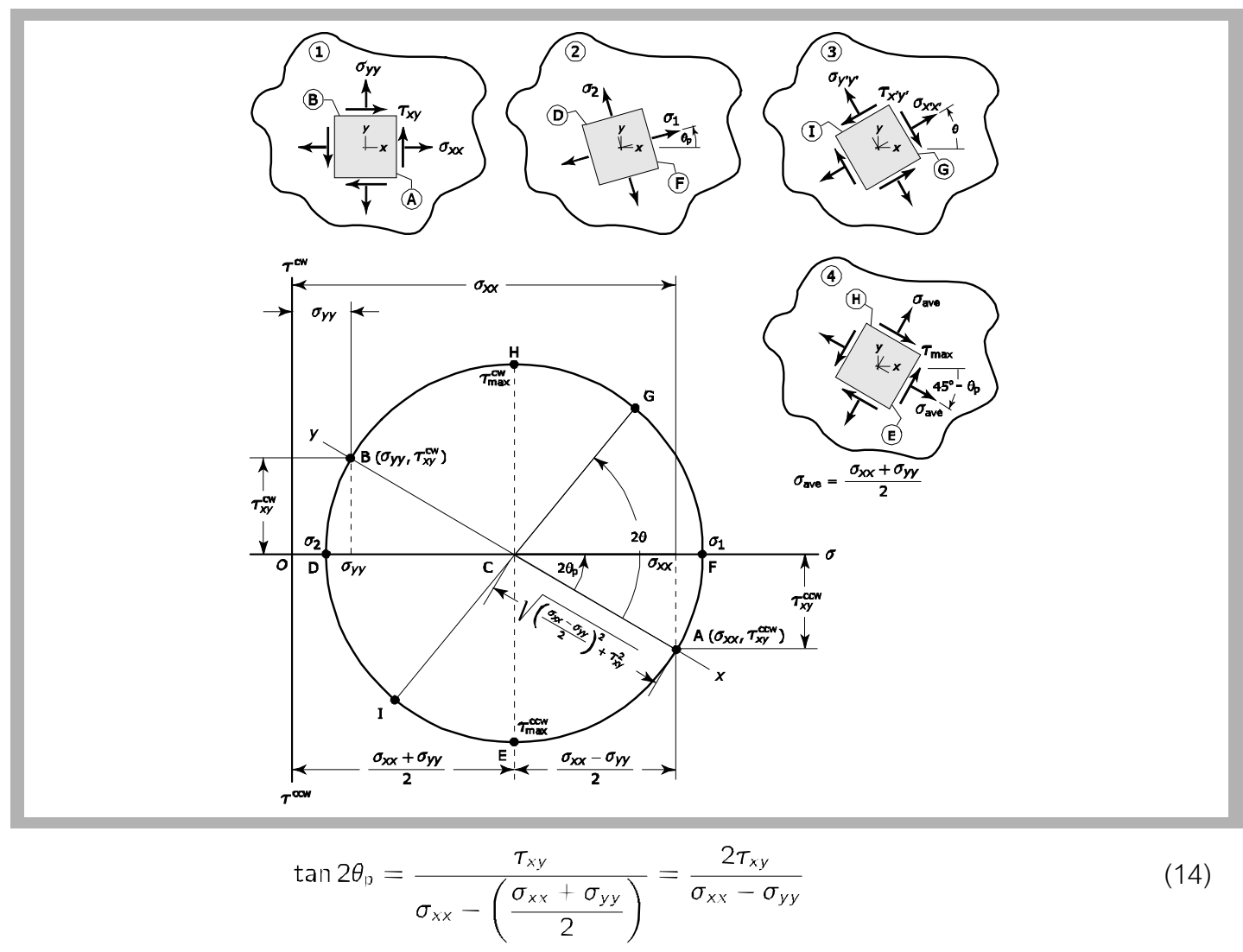

รูปที่ 2

วง ก ล ม ม อร์ พร้อม รายละเอียดที่สำคัญต่อ การคำน ว ณหาค่า องค์ประกอบความเค้น ความเค้นหลัก และ ทิศทางความเค้นหลัก

ซึ่งเหมื่อนกับสมการ (3)

\section{5 จุดขั้ว}

วิธีคุดขั้วทำให้เราเห็นภาพของเอลิเมนต์ความเค้นและทิศทางความเค้นในภาพวงกลมมอร์ได้อย่าง ชัดเจน ซึ่งทำให้ง่ายต่อการวิเคราะห์ ให้เราพิจารณาภาพวงกลมมอร์ในรูปที่ 2 และ 3 ประกอบกัน ซึ่ง ขั้นตอนของวิธีจุดขั้วมีดังนี้ [6] 
1. จากจุด $\mathrm{A}$ ในรูปที่ 2 ให้เราลากเส้นตรงขนานกับแกนพิกัด $\tau$ ไปตัดกับขอบของวงกลมมอร์ อีกด้านหนึ่งของแกนพิกัด $\sigma$ จุดตัดดังกล่าวมีชื่อเรียกว่า จุดสมนัย $A^{\prime}$ (a conjugate point $\left.A^{\prime}\right)$ (รูปที่ 3) แนวเส้น ตรงที่เชื่อมระหว่างจุด $A$ กับจุด $A^{\prime}$ จะถูกเรียกว่า เส้นอ้างอิง (reference line)

2. ใช้จุดสมนัย $A^{\prime}$ เป็นจุดขั้ว (pole) เพื่อหาค่าองค์ประกอบความเค้น ณ จุดต่างๆ บนวงกลม มอร์ ตัวอย่างเช่น หากเราต้องการทราบค่าองค์ประกอบความเค้น ณ จุด $\mathrm{G}\left(\sigma_{x^{\prime} x^{\prime} x^{\prime}} \tau_{x^{\prime} y^{\prime}}^{c w}\right)$ ใด ๆ ก็ให้ลากเส้นตรงจากจุดขั้ว $A^{\prime}$ ไปตัดกับจุด $G$ นั้น ซึ่งค่าของความเค้นสามารถวัดค่าได้ โดยตรงจากวงกลมมอร์

3. มุมเอียง $\theta$ ของเอลิเมนต์ความเค้น ณ จุด $\mathrm{G}\left(\sigma_{x^{\prime} x^{\prime}} \tau_{x^{\prime} y^{\prime}}^{\mathrm{cw}}\right)$ ก็คือ มุมระหว่างเส้นตรง $\overline{A^{\prime} A}$ กับ $\overline{A^{\prime} G}$ โดยวัดจากแนวเส้นตรง $\overline{A^{\prime} A}$ ไปยัง $\overline{A^{\prime} G}$ โดยใช้จุด $A^{\prime}$ เป็นจุดหมุน ซึ่งหากมี ทิศทางทวนเข็มก็จะมีเครื่องหมายเป็นบวกและจะเป็นลบหากมีทิศทางตรงกันข้าม สำหรับ การพิสูจน์ว่า มุมเอียง $\theta$ ของเอลิเมนต์ความเค้น ณ จุด $\mathrm{G}\left(\sigma_{x^{\prime} x^{\prime},} \tau_{x^{\prime} y^{\prime}}\right)$ นั้นเป็นมุมระหว่าง เส้น $\overline{A^{\prime} A}$ กับ $\overline{A^{\prime} G}$ สามารถกระทำได้ดังนี้ พิจารณาสามเหลี่ยม $C A^{\prime} G$ จะพบว่ามุม $\hat{C A^{\prime} G}=\hat{C G A^{\prime}}$ ดังนั้น $C \hat{A^{\prime} G}=\frac{1}{2}\left[180^{\circ}-(2 \theta-\alpha)\right]$ โดยอาศัยหลักการเดียวกันกับ สามเหลี่ยม $C A^{\prime} A$ ก็จะได้ว่า $C \hat{A}^{\prime} A=\frac{1}{2}\left[180^{\circ}-\alpha\right]$ ดังนั้น มุมเอียง $\theta$ ที่วัดจากแนวเส้น อ้างอิง $\overline{A^{\prime} A}$ ไปยังแนวเส้น $A^{\prime} G$ ก็คือ $180^{\circ}-C \hat{A^{\prime} A}-\hat{C A} \hat{A}^{\prime} G$ ซึ่งเมื่อเราแทนค่าแล้ว ก็จะ ได้ว่า $180^{\circ}-\frac{1}{2}\left(180^{\circ}-\alpha\right)-\frac{1}{2}\left[180^{\circ}-(2 \theta-\alpha)\right]=\theta$

รูปที่ 3

วงกล ม ม อร์ พร้อม รายละเอียดที่สำคัญใน การประยุกต์ใช้วิธีจุดขั้ว ในการหาความเค้นและ ทิศทาง

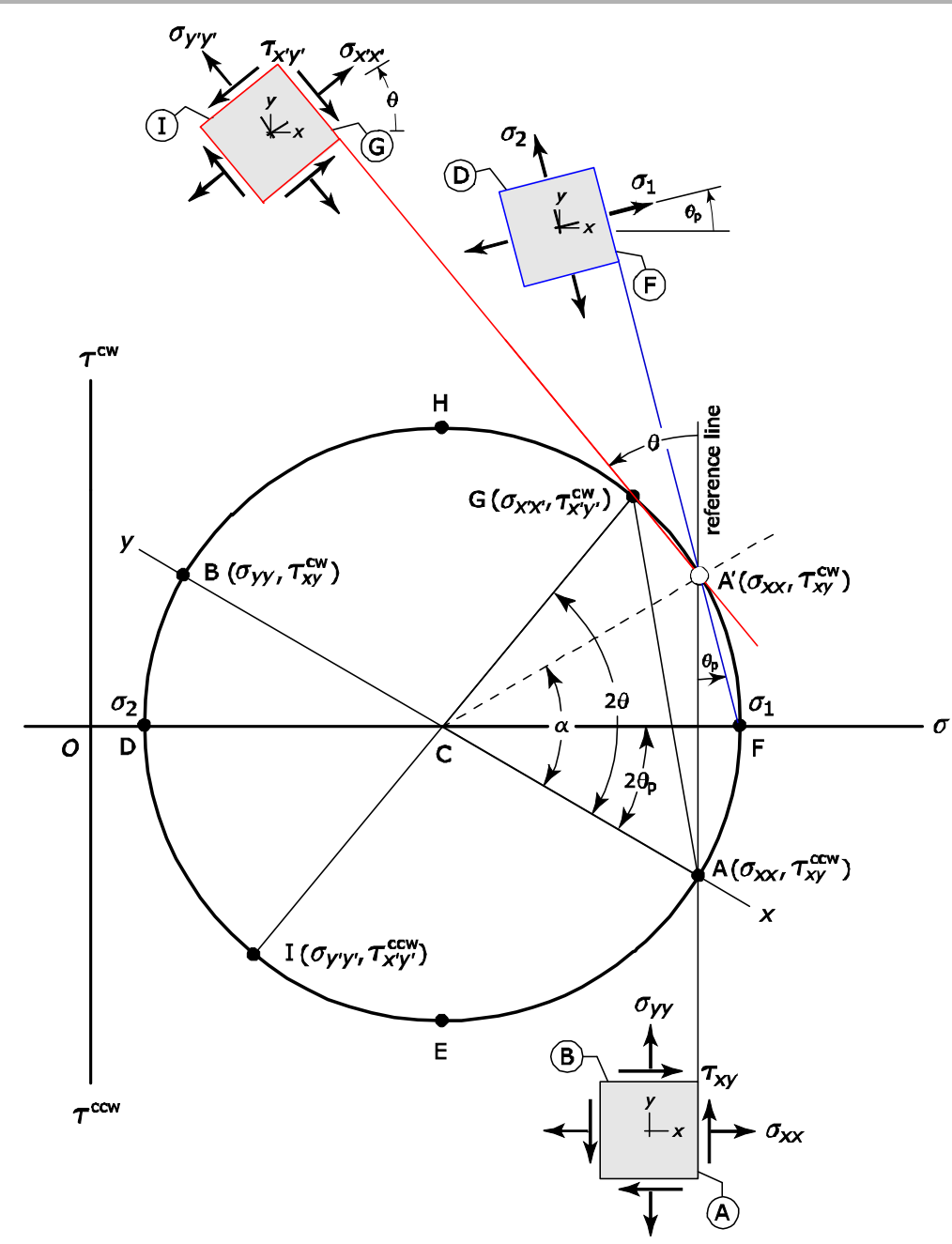


จากหลักการข้างต้น เราสามารถคำนวณหาค่าองค์ประกอบความเค้น ณ จุดใด ๆ บนเส้นวงกลมมอร์ได้ โดยการลากเส้นจากจุดขั้วไปตัดกับจุดที่ต้องการทราบค่า เช่น หากเราต้องการทราบค่าทิศทางความเค้น หลักเราก็สามารถหาค่าได้โดยการลากเส้นตรงจากจุดขั้วไปตัดที่จุด $F$ (รูปที่ 3 ) ซึ่งเป็นค่าความเค้นหลัก $\sigma_{1}$ (แนวเส้นตรง $\overline{A^{\prime} F}$ หรือเส้นสีน้ำเงิน) มุม $\theta_{p}$ ก็คือมุมระหว่างเส้นตรง $\overline{A^{\prime} A}$ กับ $\overline{A^{\prime} F}$ ซึ่งวัดจาก แนวเส้นอ้างอิงในทิศทางทวนเข็มนาฬิการอบจุดขั้ว สำหรับเอลิเมนต์ความเค้นหลักนั้นแสดงอยู่ในรูปที่ 3 กล่าวคือ เอลิเมนต์ที่ตำแหน่งหน้าตัด ( $(F)$ และ (D)

\section{III. การแปลความหมายของเฟสซ่อนรูปและเฟสเต็มรูป}

จากที่ได้กล่าวมาแล้วข้างต้นว่า สมการ (3) จะทำให้ $-45^{\circ}<\theta_{p} \leq+45^{\circ}$ เฟสซ่อนรูปนี้ทำให้เราไม่สามารถ ทราบได้ว่าค่ามุมดังกล่าวสอดคล้องกับความเค้นหลักค่าใด การเกิดเฟสซ่อนรูปสามารถสังเกตเห็นได้ชัดใน วงกลมมอร์ พิจารณาความเค้นหลัก $\sigma_{1}$ (รูปที่ 2) เป็นค่าแรก เราจะพบว่ามุม $2 \theta_{p}$ เป็นมุมระหว่างสภาวะความ เค้นที่ใช้วาดวงกลมมอร์ (เส้นตรง $\overline{A C B}$ ) กับความเค้นหลัก $\sigma_{1}$ มุม $\hat{A C F}$ จะยังคงแสดงทิศทางความเค้น หลัก $\sigma_{1}$ ตราบเท่าที่จุด $\mathrm{A}$ มีตำแหน่งไม่เกินจุด $\mathrm{E}$ หรือมุม $2 \theta_{p}>-90^{\circ}$ หรือ $\theta_{p}>-45^{\circ}$ (พิจารณาตาม หลักพีชคณิต) เมื่อใดก็ตามที่เงื่อนไขดังกล่าวข้างต้นไม่เป็นจริง กล่าวคือ จุด $A$ มีตำแหน่งอยู่เลยจุด $E$ ออกไป ความเค้นหลัก $\sigma_{1}$ จะเปลี่ยนไปกระทำบนหน้าตัดที่ค่าองค์ประกอบความเค้นบนหน้าตัดนั้นถูกใช้กำหนด ตำแหน่งจุด $\mathrm{B}\left(\right.$ หน้าตัด $y^{+}$) ทันที ในทำนองเดียวกันหากเราพิจารณาความเค้นหลัก $\sigma_{2}$ ด้วยก็จะเห็นได้ว่า $\sigma_{2}$ จะกระทำบนหน้าตัดที่ค่าองค์ประกอบความเค้นถูกใช้กำหนดตำแหน่งจุด $\mathrm{A}\left(\right.$ หน้าตัด $\left.x^{+}\right)$สิ่งที่เกิดขึ้นนี้ แสดงให้เห็นว่า ทิศทางความเค้นหลักทั้งสองจะสลับกันเมื่อ $\theta_{p}>-45^{\circ}$ (ในกรณีของจุด $\mathrm{A}$ ) และสาเหตุนี้เองที่ ทำให้เกิด เฟสซ่อนรูป

จากที่ได้กล่าวผ่านมาเราพิจารณาเฉพาะกรณีที่จุด $\mathrm{A}$ อยู่ทางด้านล่างของแกน $\sigma$ หากค่าองค์ประกอบความ เค้นเปลี่ยนไปโดยเป็นผลให้จุด $A$ เปลี่ยนตำแหน่งไปอยู่ทางด้านบนของแกน $\sigma$ และใช้วิธีการเดียวกันกับที่ อธิบายข้างต้นก็จะพบว่าจุด $\mathrm{A}$ จะต้องมีตำแหน่งไม่เกินจุด $\mathrm{H}$ หรือมุม $2 \theta_{p} \leq+90^{\circ}$ หรือ $\theta_{p} \leq+45^{\circ}$ ซึ่งถ้า หากเงื่อนไขดังกล่าวไม่เป็นจริงก็จะทำให้เกิดการสลับกันของทิศทางความเค้นหลักเช่นกัน เมื่อรวมกรณี $\theta_{p}>-45^{\circ}$ เข้ากับ $\theta_{p} \leq+45^{\circ}$ แล้วก็จะได้ย่านเฟสซ่อนรูป $-45^{\circ}<\theta_{p} \leq+45^{\circ}$ ดังที่กล่าวแล้วข้างต้น ในความเป็นจริงแล้ว เราควรเขียนว่า $-45^{\circ}<\theta_{p} \leq+45^{\circ}$ สำหรับเฟสซ่อนรูป หรือ $-90^{\circ}<\theta_{p}<+90^{\circ}$ สำหรับเฟสเต็มรูป ทั้งนี้เนื่องด้วย ฟังก์ชันแทนแจนต์และแทนเจนต์ผกผันมีความต่อเนื่องในช่วงข้างต้น กล่าวคือ กราฟของฟังก์ชันแทนแจนต์จะไม่สามารถหาค่าได้เมื่อ $2 \theta= \pm 90^{\circ}$ และแทนเจนต์ผกผันจะให้ค่า $2 \theta= \pm 90^{\circ}$ เมื่ออาร์กิวเมนต์ของฟังก์ชันมีค่าอนันต์ อย่างไรก็ตาม การแสดงผลลัพธ์ส่วนใหญ่นั้นมักจะแสดง ออกมาในลักษณะของภาพเชิงเลข (digitally graphic representation) ซึ่งอยู่ในรูปของฟังก์ชันวิยุต (discrete function) จึงทำให้นักวิจัยส่วนใหญ่ในสาขาโฟโตอิลาสติกซิตีแสดงย่านของทิศทางความเค้นหลักออกมาเป็น $-45^{\circ}<\theta_{p} \leq+45^{\circ}$ หรือ $-90^{\circ}<\theta_{p}<+90^{\circ}$ หากเราพิจารณาภาพวงกลมมอร์โดยละเอียดอีกครั้ง (รูปที่ 3) ก็จะพบว่า ทิศทางความเค้นหลัก $\sigma_{1}$ ที่เทียบกับจุด $\mathrm{A}$ นั้นคือ $2 \theta_{p} \leq+180^{\circ}$ (วัดจากจุด $\mathrm{E}$ ไปยังจุด $\mathrm{H}$ ) หรือ $\theta_{p} \leq+90^{\circ}$ ค่ามุม $90^{\circ}$ นี้ก็คือ ค่า มอดุโล (modulo) ของย่านเฟสซ่อนรูป หากเราพิจารณาภาพวงกลมมอร์ โดยละเอียดอีกครั้ง (รูปที่ 3) ก็จะพบว่า ทิศทางความเค้นหลัก $\sigma_{1}$ ที่เทียบกับจุด $\mathrm{A}$ นั้นคือ $2 \theta_{p} \leq \pm 180^{\circ}$ (วัด จากจุด $\mathrm{E}$ ไปยังจุด $\mathrm{H}$ ) หรือ $\theta_{p} \leq \pm 90^{\circ}$ ค่ามุม $90^{\circ}$ นี้คือ มอดุโล (modulo) ของย่านเฟสซ่อนรูป ในขณะที่ค่า มอดุโลของย่านเฟสเต็มรูปคือ $180^{\circ}$ ค่ามอดุโลทั้งสองนี้มีส่วนำคัญอย่างมากสำหรับการคืนรูปเฟส ที่ต้องอาศัย หลักการปฏิบัติระหว่างจุดภาพ (pixel-based methods) ตัวอย่างเช่น วิธีการใน [7] - [9] 
ตั้งแต่ที่ได้กล่าวมาข้างต้นจนถึง ณ ขณะนี้ ผู้เขียนคาดว่าผู้อ่านมีความเข้าใจเกี่ยวกับทิศทางความเค้นหลักทั้ง ในลักษณะเฟสซ่อนรูปและเฟสเต็มรูป แต่ผู้อ่านอาจจะมีคำถามที่สำคัญอีกข้อหนึ่ง กล่าวคือ การใช้เฟสซ่อนรูป และ/หรือเฟสเต็มรูปจะส่งผลอย่างไรต่อการวิเคราะห์ความเค้น คำถามนี้สามารถตอบได้โดยอาศัยสมการ (4) ประกอบการอธิบาย จากสมการ (4) เราจะพบว่า ค่าความเค้น $\sigma_{x^{\prime} x^{\prime}}$ และ $\sigma_{y^{\prime} y^{\prime}}$ จะมีค่าขึ้นอยู่กับค่าความเค้น หลัก $\sigma_{1}$ และ $\sigma_{2}$ เท่านั้น ทั้งนี้เพราะว่า $\cos (-20)=\cos 2 \theta$ แต่ในกรณีความเค้นเฉือน $\tau_{x^{\prime} y^{\prime}}$ นั้นจะมีค่า ขึ้นอยู่กับค่าความเค้นหลัก $\sigma_{1}$ และ $\sigma_{2}$ และทิศทางความเค้นหลัก $\theta$ ทั้งนี้เนื่องด้วย $\sin (-20) \neq \sin 2 \theta$ เพื่อให้เกิดความเข้าใจมากขึ้นให้เราพิจารณารูปที่ 4 ซึ่งเป็นภาพของวงกลมมอร์ที่วาดขึ้นจากสมการ (4) ประกอบกับข้อมูลในตารางที่ 2 ค่าความเค้นเฉือน $\tau_{x^{\prime} y^{\prime}}$ ที่คำนวณได้จะมีการสลับของเครื่องหมายทันทีหาก เราใช้ค่าทิศทางความเค้นหลักในย่านเฟสซ่อนรูป (ดูค่าความเค้นเฉือน $\tau_{x^{\prime} y^{\prime}}$ ในแถวที่ 3 ของตารางที่ 2 ) ซึ่ง ลักษณะเช่นนี้จะส่งผลให้ความเค้นที่ตำแหน่ง () และ () มีการพลิกกลับไปมา (flip) รอบแกน $\sigma$ ในขณะที่ ความเค้นเฉือนจะมีค่าที่ต่อเนื่อง หรือไม่เกิดการพลิกกลับของเครื่องหมายเมื่อเราใช้ค่าทิศทางความเค้นหลักใน ย่านเต็มรูป ตัวอย่างที่ได้อธิบายไปแล้วข้างต้นเป็นสิ่งยืนยันได้เป็นอย่างดีถึงความสำคัญของทิศทางความเค้น หลักในย่านเฟสเต็มรูป สำหรับรายละเอียดเพิ่มเติมเกี่ยวกับเรื่องนี้โดยพิจารณาบนฐานของโฟโตอิลาสติกซิตี สามารถค้นหาอ่านได้ที่ [10]

\section{IV. ผลการวิเคราะห์หาทิศทางความเค้นหลักเชิงจุด}

เพื่อให้เกิดความเข้าใจ ผู้เขียนจะนำเสนอตัวอย่างการคำนวณดังนี้ สมมติให้องค์ประกอบความเค้นในระบบ พิกัดฉาก $\sigma_{x x}=30 \mathrm{MPa}, \sigma_{y y}=90 \mathrm{MPa}$ และ $\tau_{x y}=40 \mathrm{MPa}$ โดยอาศัยสมการ (2) เราจะได้ค่าความเค้น ฉากเฉลี่ย $\sigma_{\text {ave }}=60 \mathrm{MPa}$ และค่าความเค้นหลัก $\sigma_{1}=110 \mathrm{MPa}$ และ $\sigma_{2}=10 \mathrm{MPa}$ ด้วยข้อมูลดังกล่าวนี้ เราสามารถคำนวณหาทิศทางความเค้นหลักได้

รูปที่ 4

วงก ล ม ม อ ร์ พ ร้อ ม รายละเอียดที่สำคัญสำหรับ การคำน ว ณ หาค่า องค์ประกอบความเค้นที่ ตำแหน่งใด ๆ เทียบกับแกน พิกัด $\sigma_{1}-\sigma_{2}$

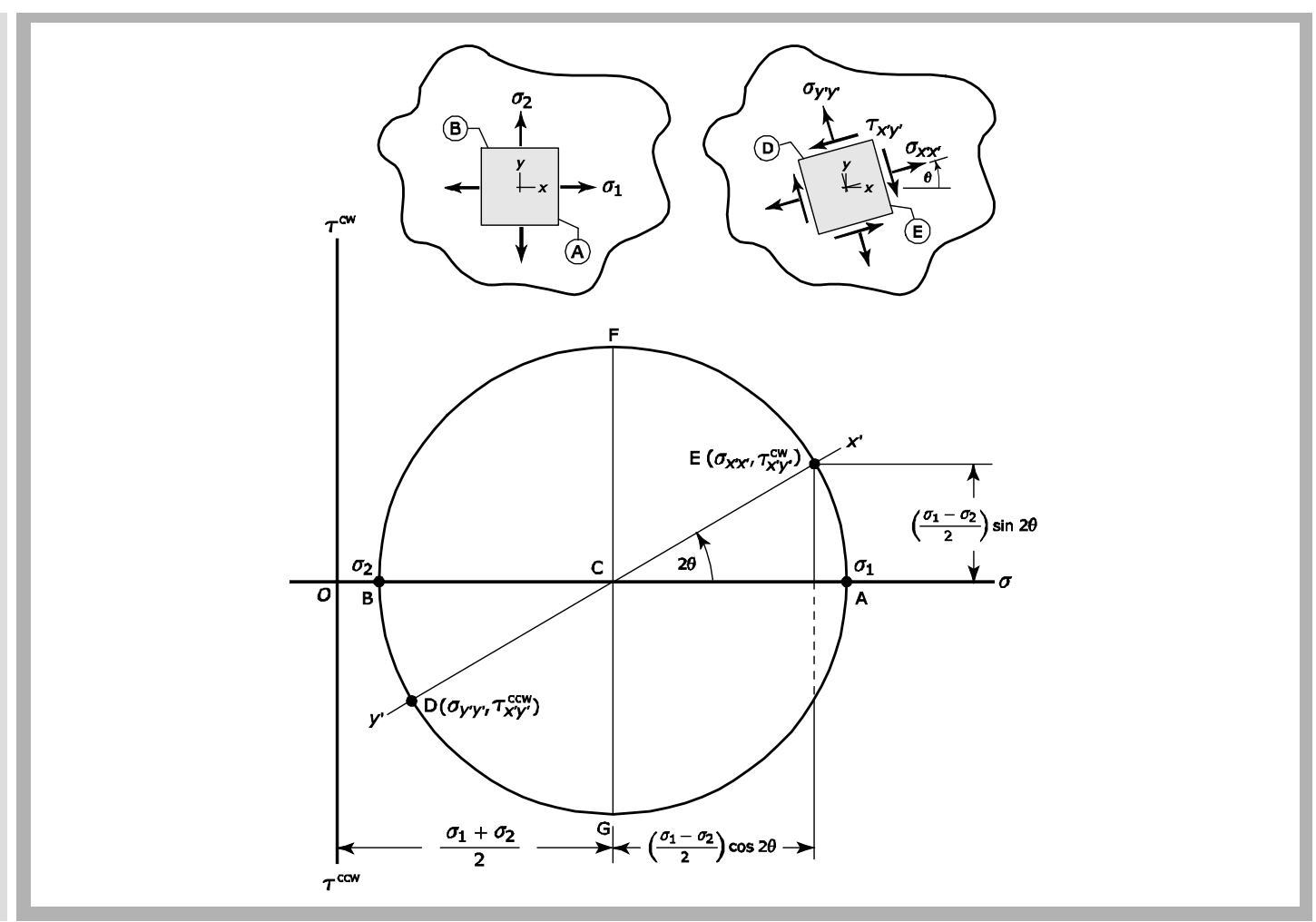




\begin{tabular}{llll}
\hline$-45^{\circ}$ ถึง $0^{\circ}$ & $0^{\circ}$ ถึง $+45^{\circ}$ & $-90^{\circ}$ ถึง $0^{\circ}$ & $0^{\circ}$ ถึง $+90^{\circ}$ \\
\hline$\tau_{x^{\prime} y^{\prime}}^{\mathrm{ccw}}\left(-30^{\circ},-30^{\circ}\right)$ & $\tau_{x^{\prime} y^{\prime}}^{\mathrm{cw}}\left(+30^{\circ},+30^{\circ}\right)$ & $\tau_{x^{\prime} y^{\prime}}^{\mathrm{ccw}}\left(-30^{\circ},-30^{\circ}\right)$ & $\tau_{x^{\prime} y^{\prime}}^{\mathrm{cw}}\left(+30^{\circ},+30^{\circ}\right)$ \\
$\tau_{x^{\prime} y^{\prime}}^{\mathrm{ccw}}\left(-45^{\circ},-45^{\circ}\right)$ & $\tau_{x^{\prime} y^{\prime}}^{\mathrm{cw}}\left(+45^{\circ},+45^{\circ}\right)$ & $\tau_{x^{\prime} y^{\prime}}^{\mathrm{ccw}}\left(-45^{\circ},-45^{\circ}\right)$ & $\tau_{x^{\prime} y^{\prime}}^{\mathrm{cw}}\left(+45^{\circ},+45^{\circ}\right)$ \\
$\tau_{x^{\prime} y^{\prime}}^{\mathrm{Cw}}\left(-55^{\circ},+35^{\circ}\right)$ & $\tau_{x^{\prime} y^{\prime}}^{\mathrm{ccw}}\left(+55^{\circ},-35^{\circ}\right)$ & $\tau_{x^{\prime} y^{\prime}}^{\mathrm{ccw}}\left(-55^{\circ},-55^{\circ}\right)$ & $\tau_{x^{\prime} y^{\prime}}^{\mathrm{cw}}\left(+55^{\circ},+55^{\circ}\right)$ \\
\hline
\end{tabular}

ค่าในทุก ๆ วงเล็บแสดงค่าทิศทางความเค้นหลัก $\theta$ ที่ใช้ในสมการลำดับสุดท้ายของสมการ (4) โดยที่ค่าแรกเป็นค่าที่ กำหนด ในขณะที่ค่าลำดับที่สองเป็นค่าที่ใช้จริง ซึ่งผลลัพธ์สุดท้ายเป็นไปตามเงื่อนไข $\sigma_{1} \geqslant \sigma_{2}$

\section{ตารางที่ 2}

ค่าความเค้นเฉือน $T_{x^{\prime} y^{\prime}}$ ที่ แปรเปลี่ยนไปตามค่า ทิศทางความเค้นหลัก $\theta$ ใน ย่านเฟสซ่อนรูปและเฟสเต็ม รูปที่สอดคล้องกับสภาวะ ความเค้นหลักในรูปที่ 4

\section{1 การคำนวณด้วยวิธีการเชิงตัวเลข}

ตารางที่ 3 แสดงผลลัพธ์ที่ได้จากการคำนวณเชิงตัวเลขจากสมการแปลงความเค้น และสมการค่า เจาะจงและเวกเตอร์เจาะจง จากข้อมูลในตารางเราจะเห็นได้ว่า ในกรณีของการใช้สมการแปลงความ เค้น (หัวข้อ 2.1) เราจะต้องคำนวณหาค่าทิศทางความเค้นหลักโดยอาศัยสมการ (3) ก่อน ในขณะที่การ ใช้สมการค่าเจาะจงและเวกเตอร์เจาะจงนั้นไม่จำเป็นต้องใช้สมการ (3) ซึ่งสามารถคำนวณได้รวดเร็ว กว่า อย่างไรก็ดี ผู้อ่านพึงระลึกถึงความแตกต่างของผลลัพธ์ที่ได้จากทั้งสองวิธีดังที่ได้กล่าวมาแล้ว กล่าวคือ วิธีแรกจะทำให้ $-45^{\circ}<\theta_{p} \leq+45^{\circ}$ และวิธีการหลังจะทำให้ $-90^{\circ}<\theta_{p} \leq+90^{\circ}$ เป็นที่ น่าสังเกตว่า หนังสือที่เกี่ยวกับรายวิชากลศาสตร์วัสดุที่เป็นภาษาไทยส่วนใหญ่มักจะกล่าวถึงเฉพาะ วิธีการแรกในการคำนวณหาทิศทางความเค้นหลักเท่านั้นและไม่ได้อธิบายเสริมในเชิงลึกเกี่ยวกับเฟส ซ่อนรูปและเฟสเต็มรูป

นอกจากนี้จะสังเกตเห็นได้ว่า การคำนวณหาทิศทางความเค้นหลักโดยอาศัยสมการค่าเจาะจงและ เวกเตอร์เจาะจงนั้นอาจไม่จำเป็นต้องใช้สมการ $(9)-(11)$ แต่สามารถใช้สมการลำดับแรกหรือลำดับที่ สองในสมการ $(7)$ ตามลำดับได้ทันที กล่าวคือ

$$
\tan \theta_{p}=\left(\frac{\sigma_{p}-\sigma_{x x}}{\tau_{x y}}\right) \text { หรือ } \tan \theta_{p}=\left(\frac{\tau_{x y}}{\sigma_{p}-\sigma_{y y}}\right)
$$

สาเหตุที่เราสามารถใช้สมการ (15) ได้ก็เพราะว่าในแต่ละสมการนั้นมีตัวแปรเพียงตัวเดียวเท่านั้น กล่าวคือ มุม $\theta_{p}$ ดังนั้นจากหลักการทางคณิตศาสตร์ที่ว่า ตัวแปรเดียวและสมการเดียว เราสามารถหา ค่าตัวแปรนั้นได้ พึงสังเกตว่า หากเรานำสมการทั้งสองในสมการ (15) มาเท่ากัน และจัดสมการใหม่ก็จะ ได้สมการกำลังสองในรูปของความเค้นหลัก $\theta_{p}$ ซึ่งเมื่อเราแก้สมการดังกล่าวด้วยสูตรการแก้สมการ กำลังสอง (quadratic equation) เราก็จะได้สมการที่ใช้คำนวณหาความเค้นหลัก เช่นเดียวกัน (สมการ (2)) จากที่กล่าวข้างต้นจึงมีคำถามอยู่ว่า ถ้าเป็นดังนั้นเหตุใดเราจึงยังต้องใช้สมการ $(9)-(11)$ คำตอบก็ คือว่า ในการวิเคราะห์ปัญหาในทางปฏิบัตินั้นเรามักจะวิเคราะห์ปัญหาในลักษณะ 3 มิติ ดังนั้นเราจึง สามารถเขียนสมการ $(5)$ และ $(6)$ ได้ใหม่คือ

$$
\begin{aligned}
& \left(\sigma_{x x}-\sigma_{p}\right) n_{x}+\tau_{x y}+\tau_{x z} n_{z}=0 \\
& \tau_{x y} n_{x}+\left(\sigma_{y y}-\sigma_{p}\right) n_{y}+\tau_{y z} n_{z}=0 \\
& \tau_{x z} n_{x}+\tau_{y z} n_{y}+\left(\sigma_{z z}-\sigma_{p}\right) n_{z}=0
\end{aligned}
$$


และ

$$
n_{x}^{2}+n_{y}^{2}+n_{z}^{2}=1
$$

จากสมการ (16) เราจะเห็นได้ว่า ความสัมพันธ์ในลำดับหนึ่งๆ นั้น จะมีสามตัวแปรที่ไม่ทราบค่า กล่าวคือ $n_{x} n_{y}$ และ $n_{z}$ ซึ่งในแก้ปัญหา เราไม่สามารถใช้เพียงความสัมพันธ์ในลำดับนั้นๆ ในการแก้ สมการได้ แต่จำเป็นต้องใช้ทั้งระบบสมการ กล่าวคือ หาความสัมพันธ์ระหว่างโคไซน์แสดงทิศทางโดยใช้ หลักการเดียวกันกับที่ใช้พิสูจน์

\begin{tabular}{|c|c|c|c|}
\hline วิธีการ & มุม $\theta_{p}$ & มุม $\theta_{p}$ สำหรับ $\sigma_{1}$ & มุม $\theta_{p}$ สำหรับ $\sigma_{2}$ \\
\hline สมการแปลงความเค้น (หัวข้อ 2.1) & $-26.56^{\circ}, 63.44^{\circ}$ & $63.44^{\circ}$ & $-26.56^{\circ}$ \\
\hline $\begin{array}{l}\text { สมการค่าเจาะจง และเวกเตอร์เจาะจง } \\
\text { (หัวข้อ 2.2) }\end{array}$ & - & $63.44^{\circ}$ & $-26.56^{\circ}$ \\
\hline
\end{tabular}

ทราบสมการ $(9)$ - (11) หรือใช้วิธีการแก้ปัญหาเชิงเลข (numerical techniques) ซึ่งวิธีการแก้ปัญหา เชิงเลขนี้นิยมใช้ในวิธีไฟไนต์เอลิเมนต์ และด้วยเหตุผลนี้เอง หากเราวิเคราะห์ความเค้นด้วยซอฟท์แวร์ ไฟไนต์เอลิเมนต์ ขนาดและทิศทางขององค์ประกอบความเค้น ความเค้นหลักหรือค่าอื่นใดที่เกี่ยวข้องก็ สามารถแสดงออกมาเป็นภาพได้โดยง่าย ทั้งนี้เพราะเราจะทราบค่าต่าง ๆ ที่โหนด (node) ของเอลิ เมนต์ อย่างไรก็ดี ผู้วิเคราะห์ปัญหาที่ใช้ซอฟท์แวร์ไฟไนต์เอลิเมนต์ในการวิเคราะห์ความเค้นจะต้องมี ความระมัดระวังอย่างมากในการกำหนดเงื่อนไขขอบเขตให้กับปัญหาที่กำลังทำการวิเคราะห์ หากผู้ วิเคราะห์กำหนดเงื่อนไขขอบเขตไม่ถูกต้องหรือไม่เหมาะสมแล้ว ก็จะส่งผลให้ค่าต่างๆ ที่อยู่ภายในเอลิ เมนต์มีความผิดพลาดไปด้วย ซึ่งปัญหานี้ถือเป็นปัญหาหลักในการวิเคราะห์ความเค้นโดยใช้ไฟไนต์เอลิ เมนต์ อนึ่ง ผู้ที่สนใจสามารถสืบค้นเพิ่มเติมเกี่ยวกับวิธีการผสมสานระหว่างโฟโตอิลาสติกซิตีเข้ากับไฟ ไนต์เอลิเมนต์ได้ที่ [11]

อย่างไรก็ดี เนื่องจากระบบสมการ (16) เป็นระบบสมการแบบเอกพันธ์ (system of homogeneous equations) ผลเฉลยไม่สำคัญ (non-trivial solutions) ของระบบสมการนี้ก็คือ $n_{x}=n_{y}=n_{z}=0$ ซึ่ง ไม่เป็นจริงตามเงื่อนไขในสมการ (17) ดังนั้น เราจึงไม่สามารถแก้สมการได้แม้ว่าจะมีสามตัวแปรและ สามสมการก็ตาม แต่ต้องอาศัยสมการ (17) เข้ามาช่วย กล่าวคือ เลือกใช้สมการในสมการ (6) เพียงสอง สมการเท่านั้น (คู่ใดก็ได้) ร่วมกับสมการ (17) เราก็จะสามารถหาค่าโคไซน์แสดงทิศทางความเค้นหลัก ทั้งสามค่าที่สอดคล้องกับความเค้นหลัก $\sigma_{1} \sigma_{2}$ และ $\sigma_{3}$ ได้

\section{2 การคำนวณวงกลมมอร์และจุดขั้ว}

ผลลัพธ์ที่ได้จากวงกลมมอร์และจุดขั้วแสดงอยู่ในรูปที่ 5 จากรูปจุด $A^{\prime}(30,40)$ เป็นจุดขั้ว จาก หลักการที่ได้กล่าวไว้ในหัวข้อ 2.3 เราก็จะได้ทิศทางความเค้นหลัก $\sigma_{2}$ โดยการลากเส้นตรงจากจุดขั้ว ไปตัดกับจุด $E$ มุมระหว่างแนวเส้นอ้างอิงกับเส้นตรง $\overline{A^{\prime} E}$ ที่วัดในทิศทางตามเข็มนาฬิกาก็คือมุม $\theta_{p 2}$ ดังนั้น เอลิเมนต์ความเค้นหลักก็จะอยู่ที่ตำแหน่งหน้าตัด (E) และ (G) จากการวัดมุมโดยใช้เครื่องมือวัด มุม เราจะได้ว่ามุม $\theta_{p 2} \approx-26^{\circ}$ และ $\theta_{p 1} \approx-64^{\circ}$ (ความถูกต้องของค่ามุมที่วัดได้นี้ขึ้นอยู่กับ 
เครื่องมือที่ใช้วาดวงกลมมอร์และขนาดของวงกลมมอร์) สำหรับทิศทางของความเค้นเฉือนค่าสูงสุด $\tau_{\max }$ สามารถหาค่าได้โดยวัดมุมจากเส้นอ้างอิงไปยังเส้นตรง $\overline{A^{\prime} D}$ ในทิศทางตามเข็มนาฬิกา ซึ่งมี ค่าประมาณ $-71^{\circ}$ และเอลิเมนต์ความเค้นก็จะอยู่ที่ตำแหน่งหน้าตัด () และ $(\odot)$ ผู้อ่านพึงสังเกตว่า มุม ของความเค้นเฉือนจะอยู่ห่างจากทิศทางความเค้นหลักเท่ากับ $\pm 45^{\circ}$ ดังนั้น ทิศทางของความเค้นเฉือน ก็คือ $-26^{\circ}-45^{\circ}=-71^{\circ}$ และ $-26^{\circ}+45^{\circ}=19^{\circ}$ สำหรับค่ามุม $19^{\circ}$ สามารถหาค่าได้โดยตรงใน วงกลมมอร์โดยลากเส้นตรงจากจุดขั้วไปตัดจุด $F$

\section{V. ผลการวิเคราะห์หาทิศทางความเค้นหลักเชิงสนาม}

จากตัวอย่างในหัวข้อ IV ที่ผ่านมาจะเห็นได้ว่า เราสามารถคำนวณหาค่าความเค้นหลักและทิศทางได้โดยง่าย โดยใช้สมการแปลงความเค้น วงกลมมอร์และจุดขั้ว และสมการค่าเจาะจงและเวกเตอร์เจาะจง อย่างไรก็ตาม สิ่งสำคัญที่เราจะต้องระลึกไว้ว่า ผลลัพธ์ที่เราคำนวณได้เป็นของสภาวะความเค้น ณ จุดใดจุดหนึ่งในชิ้นส่วน หรือโครงสร้างที่รับภาระเท่านั้น ดังนั้น จึงมีคำถามขึ้นมาว่า เราจะต้องคำนวณหาค่าความเค้นหรือวาดวงกลม มอร์เป็นจำนวนมากน้อยเท่าใดเพื่อที่จะให้ครอบคลุมทั่วทั้งชิ้นส่วนนั้น คำตอบก็คือ จำนวนอนันต์ ทั้งนี้เนื่องจาก ความเค้นเป็นปริมาณที่มีความต่อเนื่องทั่วทั้งพื้นที่ (พิจารณาสมการสมดุลของความเค้น [4])

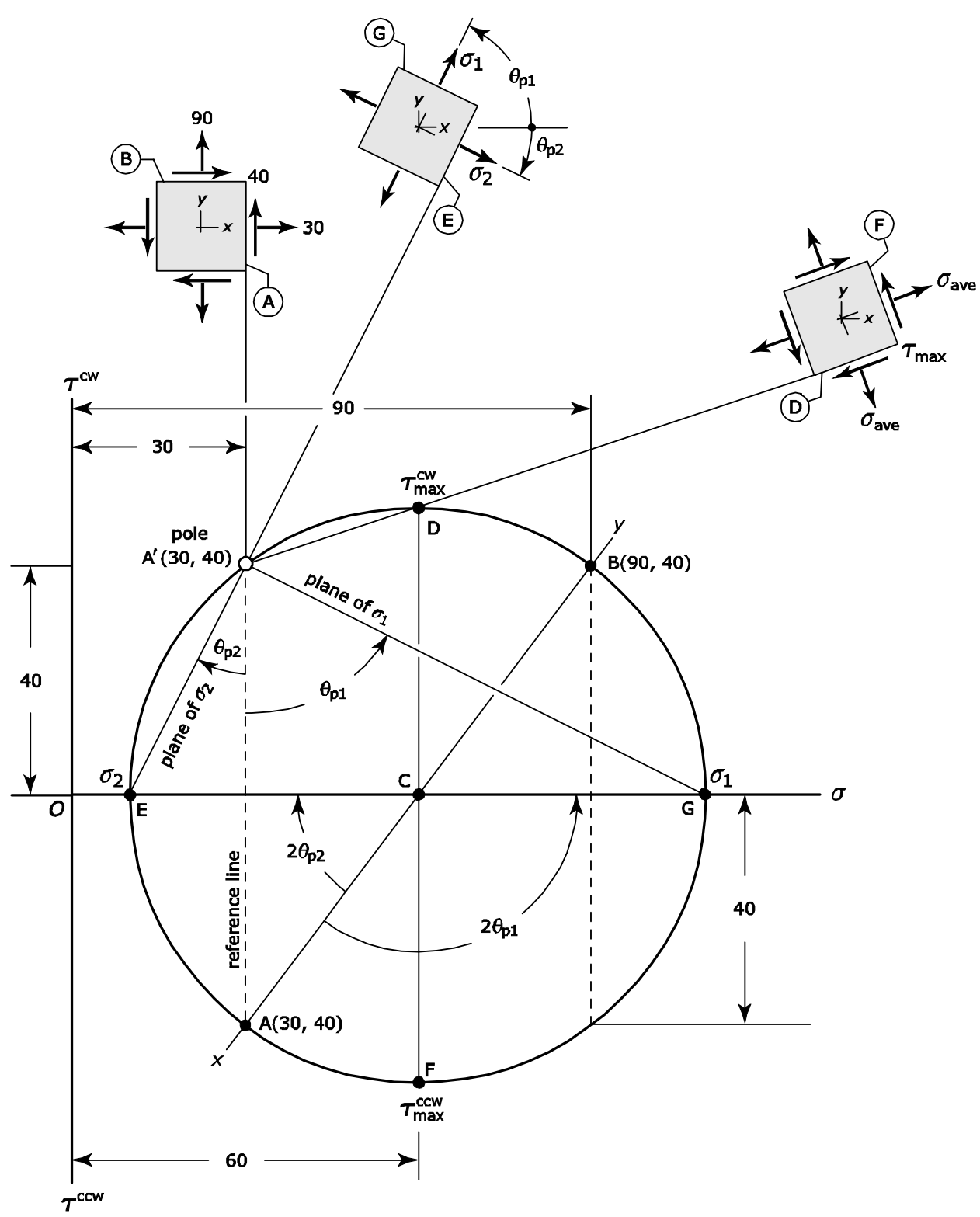

รูปที่ 5

วงกลมมอร์ และค่าความเค้น และทิศทางที่หาโดยจุดขั้ว 
เพื่อให้เกิดความเข้าใจเชิงลึกแก่ผู้อ่าน ผู้เขียนจะนำเสนอตัวอย่างการคำนวณผ่านผลเฉลยแม่นตรงของปัญหา แผ่นจานกลมรับแรงเข้มกดในแนวเส้นผ่านศูนย์กลาง

\section{1 ผลเฉลยแม่นตรงของปัญหาแผ่นจานกลมรับแรงเข้มกดในแนวเส้นผ่าน ศูนย์กลาง}

สมการองค์ประกอบความเค้น $\sigma_{x x}, \sigma_{y y}$ และ $\tau_{x y}$ ที่เป็นผลเฉลยแม่นตรงของปัญหาแผ่นจานกลมรับ แรงเข้มกดในแนวเส้นผ่านศูนย์กลาง (รูปที่ 6 ) สามารถเขียนได้ดังนี้ [12]

$$
\left\{\begin{array}{l}
\sigma_{x x} \\
\sigma_{y y} \\
\tau_{x y}
\end{array}\right\}=\frac{-2 F}{\pi t}\left\{\begin{array}{l}
\frac{(R-y) x^{2}}{\left[x^{2}+(R-y)^{2}\right]^{2}}+\frac{(R+y) x^{2}}{\left[x^{2}+(R+y)^{2}\right]^{2}}-\frac{1}{2 R} \\
\frac{(R-y)^{3}}{\left[x^{2}+(R-y)^{2}\right]^{2}}+\frac{(R+y)^{3}}{\left[x^{2}+(R+y)^{2}\right]^{2}}-\frac{1}{2 R} \\
\frac{(R+y)^{2} x}{\left[x^{2}+(R+y)^{2}\right]^{2}}-\frac{(R-y)^{2} x}{\left[x^{2}+(R-y)^{2}\right]^{2}}
\end{array}\right\}
$$

รูปที่ 6

ลักษณะเชิงรูปร่างและมิติ ของปัญหาแผ่นจานกลม รับ แรง เข้มกด ในแนว เส้นผ่านศูนย์กลาง

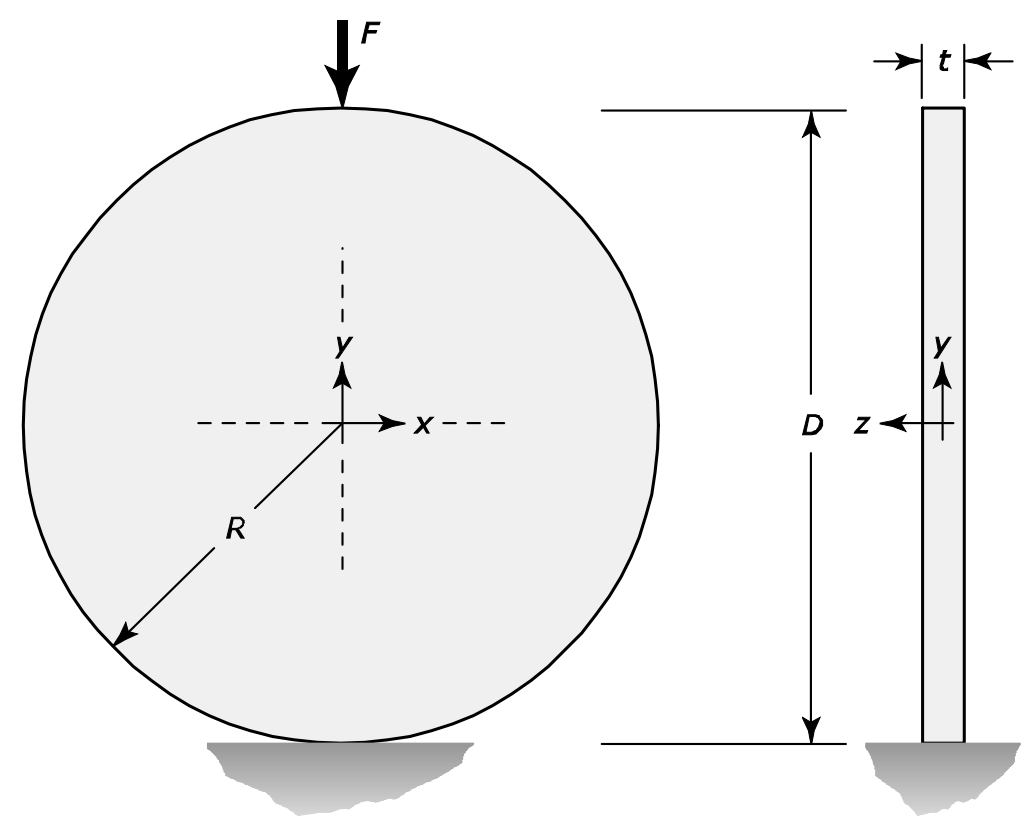

โดยที่ $R$ และ $D$ คือ รัศมีและเส้นผ่านศูนย์กลางของแผ่นจานกลม ตามลำดับ $F$ คือแรงเข้มกด และ $t$ คือความหนาของแผ่นจานกลม สำหรับผลเฉลยแม่นตรงนี้ได้มาจากทฤษฎีสภาพยืดหยุ่น หากเราแทน ค่าองค์ประกอบความเค้นจากสมการ (18) ลงในสมการ (3) ก็จะสามารถหาค่าทิศทางของความเค้น หลักได้ เนื่องจากว่า พจน์ $-2 F / \pi t$ เป็นพจน์ร่วมขององค์ประกอบความเค้นทั้งสามค่า ดังนั้นค่า ทิศทางความเค้นหลัก $\theta_{p}$ ที่คำนวณหาได้จากสมการที่ (3) จึงไม่ขึ้นอยู่กับขนาดของแรงเข้มกด $F$ และ ความหนา $t$ สำหรับค่าทิศทางความเค้นหลักของปัญหานี้สามารถคำนวณหาได้โดยง่ายโดยอาศัย ความสัมพันธ์ดังนี้ [11]

$$
\tan \theta_{p}=\frac{2 x y}{R^{2}+x^{2}-y^{2}}
$$


ซึ่งจะเห็นได้ว่าค่ามุม $\theta_{p}$ ไม่ได้ขึ้นอยู่กับแรงและความหนาของวัตถุดังที่ได้กล่าวข้างต้น เป็นความโชคดี ของปัญหานี้ที่สามารถพิสูจน์ทราบสมการ (19) ได้ อย่างไรก็ตาม ยังมีผลเฉลยของปัญหาอีกหลาย ปัญหาในทางปฏิบัติที่ไม่สามารถหาความสัมพันธ์ของทิศทางความเค้นหลักในรูปแบบอย่างง่ายได้เนื่อง ด้วยความซับซ้อนของผลเฉลยขององค์ประกอบความเค้น ตัวอย่างของผลเฉลยของแผ่นวงแหวนกลมรับ แรงเข้มกดในแนวเส้นผ่านศูนย์กลางสามารถยืนยันคำอธิบายนี้ได้ [12] ดังนั้นการใช้วิธีการที่กล่าวแล้ว ในหัวข้อ 2.12 .2 หรือ 2.3 จะมีความเหมาะสมมากกว่า ผู้อ่านพึงระลึกไว้ว่า การแก้ปัญหาเชิงวิเคราะห์ นั้นมีข้อจำกัดเนื่องด้วยไม่สามารถหาผลเฉลยแม่นตรงได้ครอบคลุมทุกปัญหาที่เกิดขึ้นจริง ด้วยเหตุนี้ การคำนวณเชิงตัวเลข (บนเครื่องคอมพิวเตอร์) หรือการวิเคราะห์เชิงทดลองจึงยังเป็นเรื่องที่มีความ จำเป็นอย่างยิ่ง สำหรับความสัมพันธ์ระหว่างวิธีการวิเคราะห์ความเค้นสามารถสืบค้นได้ที่ [13]

พิจารณาสมการ (18) จะพบว่า ณ จุดที่แรงกระทำ $P(0, \pm R)$ องค์ประกอบความเค้น $\sigma_{x x}, \sigma_{y y}$ และ $\tau_{x y}$ จะมีค่าเข้าใกล้ค่าอนันต์ ในขณะที่จุด $\mathrm{P}(0,0)$ องค์ประกอบความเค้น $\sigma_{1}=\sigma_{x x}=F / \pi R t$, $\sigma_{2}=\sigma_{y y}=-3 F / \pi R t$ และ $\tau_{x y}=0$ จากการพิจารณาทั้งสามจุด เราสามารถแปลความได้ว่า ความเค้น $\sigma_{x x}$ จะเป็นความเค้นดึงเสมอ และความเค้น $\sigma_{y}$ ก็จะเป็นความเค้นอัดเสมอเช่นกัน สิ่งที่ เกิดขึ้นสอดคล้องกับเป็นจริงโดยพิจารณาว่าเรากำลังออกแรงกดก้อนเยลลีกลม ซึ่งเมื่อเกิดความเค้นใน ก้อนเยลลีนั้นแล้ว ด้านข้างจะพองหรือยืดตัวออกในขณะที่ด้านบนและล่างจะยุบตัวเข้าหากัน กล่าวคือ จากรูปร่างกลมจะค่อย ๆ กลายเป็นรูปรีตามขนาดของแรงกด

ต่อไปให้เราพิจารณาหาค่าทิศทางความเค้นหลัก โดยกำหนดเงื่อนไข $F=300 \mathrm{~N} D=30 \mathrm{~mm}$ และ $t=6 \mathrm{~mm}$ ซึ่งผลลัพธ์จากการคำนวณแสดงในตารางที่ 4

\begin{tabular}{|c|c|c|c|}
\hline จุดที่พิจารณา* & สมการ (3) & สมการ (15) ซ้าย * & สมการ $(19)^{\dagger}$ \\
\hline จตุภาคที่ $1 \mathrm{P}(+4.5,+7.5)$ & $\theta_{\mathrm{p} 1,2}=+19.65^{\circ},-70.35^{\circ}$ & $\theta_{p 1,2}=+19.65^{\circ},-70.35^{\circ}$ & $\theta_{p}=+19.65^{\circ}$ \\
\hline จตุภาคที่ $2 \mathrm{P}(-4.5,+7.5)$ & $\theta_{p 1,2}=-19.65^{\circ},+70.35^{\circ}$ & $\theta_{p 1,2}=-19.65^{\circ},+70.35^{\circ}$ & $\theta_{p}--19.65^{\circ}$ \\
\hline จตุภาคที่ $3 \mathrm{P}(-4.5,-7.5)$ & $6_{\mathrm{pl}, 2}=+19.65^{\circ},-70.35^{\circ}$ & $\theta_{p 1,2}=+19.65^{\circ},-70.35^{\circ}$ & $\theta_{p}=+19.65^{\circ}$ \\
\hline จตุภาคที่ $4 \mathrm{P}(+4.5,-7.5)$ & $G_{p 1,2}=-19.65^{\circ},+70.35^{\circ}$ & $\theta_{p 1,2}=-19.65^{\circ},+70.35^{\circ}$ & $\theta_{\mathrm{p}}=-19.65^{\circ}$ \\
\hline จตุภาคที่ $1 \mathrm{P}(+4.5,+13)$ & $\theta_{\mathrm{p} 1,2}=+56.90^{\circ},-33.10^{\circ}$ & $\theta_{\mathrm{p} 1,2}=+56.90^{\circ},-33.10^{\circ}$ & $\theta_{\mathrm{p}}=+56.90^{\circ}$ \\
\hline จตุภาคที่ $2 \mathrm{P}(-4.5,+13)$ & $\theta_{\mathrm{p} 1,2}=-56.90^{\circ},+33.10^{\circ} \dot{\ddagger}$ & $\theta_{\mathrm{p} 1,2}=-56.90^{\circ},+33.10^{\circ}$ & $\theta_{p}=-56.90^{\circ}$ \\
\hline จตุภาคที่ $3 \mathrm{P}(-4.5,-13)$ & $\theta_{\mathrm{pl}, 2}=+56.90^{\circ},-33.10^{\circ}$ & $\theta_{\mathrm{p} 1,2}=+56.90^{\circ},-33.10^{\circ}$ & $\theta_{p}=+56.90^{\circ}$ \\
\hline จตุภาคที่ $4 \mathrm{P}(+4.5,-13)$ & $G_{\mathrm{p} 1,2}=-56.90^{\circ},+33.10^{\circ} \mp$ & $\theta_{\mathrm{p} 1,2}=-56.90^{\circ},+33.10^{\circ}$ & $\theta_{p}=-56.90^{\circ}$ \\
\hline
\end{tabular}

* จุดที่พิจารณาในสดมภ์ที่ 1 สี่ลำดับแรกคือ จุดสีขาว ส่วนที่เหลือคือจุดสีแดง ในรูปที่ 7

* ผลลัพธ์ที่ได้จากสมการ (15) ทางด้านขวามือจะให้ผลลัพธ์ที่เหมือนกัน

† ค่าที่คำนวณได้จะมีความต่อเนื่อง แต่ไม่สามารถระบุได้ว่าสอดคล้องกับความเค้นหลักค่าใด อย่างไรก็ตามจากการ เปรียบเทียบกับค่าในสดมภ์ที่ 3 ก็จะพบว่าเป็นของความเค้นหลัก $\sigma_{1}$

₹ ค่าที่แสดงเป็นค่าที่ผ่านการจับคู่ที่ถูกต้องตามขั้นตอนในหัวข้อที่ 2.1 แล้ว อย่างไรก็ตาม ค่าที่คำนวณได้จากสมการ (3) ใน ครั้งแรกก่อนการจับคู่จะสลับตำแหน่งกัน กล่าวคือ $\theta_{\mathrm{p} 1,2}= \pm 33.10^{\circ}, \mp 56.90^{\circ}$ สำหรับค่าทิศทางความเค้นหลักในสดมภ์ ที่ 3 และ 4 ไม่ต้องทำการจับคู่แต่อย่างใด

ตารางที่ 4

ผลการคำนวณหาค่าทิศทาง ความเค้นหลักโดยสมการ แปลงความเค้น สมการค่า เจาะจงและเวกเตอร์เจาะจง และสมการจากทฤษฎีสภาพ ยืดหย่น 
พึงสังเกตว่า ไม่ว่าเราจะกำหนดค่าแรงกดเป็นเท่าใดก็ตาม ค่าทิศทางความเค้นหลักก็ยังคงมีค่าเท่าเดิม (พิจารณาสมการ 19) เพื่อให้เกิดความเข้าใจโดยถ่องแท้ ผู้เขียนจะขออธิบายข้อมูลต่าง ๆ ในตารางที่ 4 พร้อมกับภาพสนามความเค้นในหัวข้อถัดไป

\section{2 ภาพสนามทิศทางความเค้นหลัก}

รูปที่ 7 แสดงภาพสนามทิศทางความเค้นหลักที่สร้างขึ้นด้วยคอมพิวเตอร์ โดยอาศัยหลักการใน [[13]] รูปที่ 7 ก และ 7 ข เป็นภาพสนามทิศทางความเค้นหลักในย่านเฟสซ่อนรูป $-45^{\circ}<\theta_{p} \leq+45^{\circ}$ และ เฟสเต็มรูป $-90^{\circ}<\theta_{p} \leq+90^{\circ}$ ตามลำดับ โดยที่จำนวนจุดภาพที่อยู่ในอาณาบริเวณตัวแบบมี ประมาณ 121000 จุดภาพ พิจารณาภาพเฟสซ่อนรูปจะพบว่าการคำนวณหาค่าทิศทางความเค้นหลัก โดยใช้สมการ (3) จะให้ค่าที่ต่อเนื่องในพื้นที่ใหญ่ (ทิศทางความเค้นหลัก $\sigma_{1}$ ) ทั้งสี่จุดสีขาว อย่างไรก็ ตาม เมื่อจุดที่พิจารณาเป็นจุดสีแดง ค่าทิศทางความเค้นหลักที่คำนวณได้จากสมการ (3) จะเกิดการ สลับค่าทันที่ (ตารางที่ 4) ตัวอย่างเช่น จุด $P(4.5,13)$ (พิจารณารูปที่ 7ค ประกอบ) ค่าที่ควรเป็นทิศทาง ความเค้นหลัก $\sigma_{1}$ คือ กล่าวคือ $\theta_{p 1}=56.90^{\circ}$ (ลูกศรสีแดง) แต่เนื่องจากค่าดังกล่าวมีค่ามากกว่า $45^{\circ}$ ดังนั้น ค่าที่แสดงออกมาคือ $\theta_{p 2}=-33.10^{\circ}$ (ลูกศรสีน้ำเงิน) และลักษณะเช่นนี้จะเป็นจริงสำหรับ อีกสามจุดสีแดงที่เหลือ ณ บริเวณดังกล่าวเราจะเห็นได้ว่า ลูกศรสีแดงจะสลับตำแหน่งกับลูกศรสีน้ำเงิน ซึ่งสังเกตได้จากรูปเอลิเมนต์ขนาดเล็กในรูปที่ 7ค ผู้อ่านพึงระลึกไว้เสมอว่า แกน $0^{\circ}$ ของลูกศรสีแดงคือ แนวแกน $x$ ขณะที่แกน $0^{\circ}$ ของลูกศรสีน้ำเงินคือ แนวแกน $y$ แนวเส้นที่เป็นขอบเขตระหว่างสีดำกับสี ขาวนั้นมีชื่อเรียกว่า 'เส้นเฟสพลิกกลับ' (phase-flipped line) สำหรับการศึกษาในสาขาโฟโตอิลาสติกซิ ตีนั้นจะเรียกว่า 'ริ้วไอโซคลินิก' (isoclinic fringes)

รูปที่ 7 แสดงภาพเฟสเต็มรูปของทิศทางความเค้นหลัก $\sigma_{1}$ ส่วนภาพเฟสเต็มรูปของทิศทางความเค้น หลัก $\sigma_{2}$ นั้นจะภาพสะท้อนของรูปที่ 7 ในแนวนอน (ไม่ได้แสดงรูปภาพ) จากรูปเราจะเห็นได้ว่า ลูกศรสี แดงและสีน้ำเงินมีความต่อเนื่องทั่วทั้งสนาม พิจารณาแนวเส้นของลูกศรสีแดงจะพบว่า ความเค้นหลัก $\sigma_{1}$ พยายามที่จะทำให้แผ่นจานกลมยืดตัวออกทางด้านข้าง ขณะที่ลูกศรสีน้ำเงิน ซึ่งแสดงความเค้น หลัก $\sigma_{2}$ พยายามทำให้แผ่นจานกลมยุบตัว กล่าวคือ ความเค้นหลัก $\sigma_{1}$ เป็นความเค้นดึง และความ เค้นหลัก $\sigma_{2}$ เป็นความเค้นอัด ซึ่งสอดคล้องกับตัวอย่างในเรื่องเยลลีก้อนกลม

จากที่ได้กล่าวมาแล้วในหัวข้อ 5.1 ว่า การคำนวณค่าทิศทางความเค้นหลักเชิงสนามนั้นจำเป็นอย่างยิ่ง ที่ต้องใช้เครื่องคอมพิวเตอร์ ซึ่งในบางครั้งอาจมีปัญหาเกี่ยวกับค่าของอาร์กิวเมนต์ในฟังก์ชันแทนเจนต์ ผกผัน กล่าวคือ ที่จุด $P( \pm x, 0)$ ค่าความเค้นเฉือน $\tau_{x y}=0$ ดังนั้น $\sigma_{1}=\sigma_{x x}$ และ $\sigma_{2}=\sigma_{y y}$ ซึ่ง ส่งผลให้ไม่สามารถคำนวณหาค่าทิศทางความเค้นหลักโดยสมการ (11) และ/หรือ (15) ด้วยเครื่อง คอมพิวเตอร์ได้ ทั้งนี้เนื่องด้วยตัวหารในสมการทั้งสองนั้นจะมีค่าเท่ากับศูนย์ (ภาษาโปรแกรมต่าง ๆ จะ มีคำเตือนออกมาว่า ตัวหารมีค่าเท่ากับศูนย์ หรือมีค่าเข้าใกล้ศูนย์มากๆ จนกระทั่งไม่สามารถจัดเก็บค่า ผลลัพธ์จากการหารลงในชนิดตัวแปรที่กำหนดไว้ได้) อย่างไรก็ดี เราสามารถประมาณค่าทิศทางความ เค้นหลักได้โดยการกำหนดหรือสมมติให้ผลหารนั้นมีค่ามากเพียงพอ แล้วดำเนินการคำนวณตามปกติ ซึ่งผลจากการกระทำดังที่กล่าวทำให้ทราบว่า ณ จุด $P( \pm x, 0) \theta_{p 1}=0^{\circ}$ และ $\theta_{p 2}=90^{\circ}$ ซึ่งตรงกัน กับลูกศรสีแดงและสีน้ำเงินในรูปที่ 7 ค และ 7 ง พึงสังเกตว่า ค่าทิศทางความเค้นหลัก ณ จุด $P(0, \pm y)$ จะมีค่าในลักษณะเดียวกัน ลูกศรทั้งสองสีใช้แสดงทิศทางความเค้นหลักเท่านั้น ขนาดของลูกศรมิได้มี ความสัมพันธ์กับขนาดของความเค้นแต่อย่างใด 

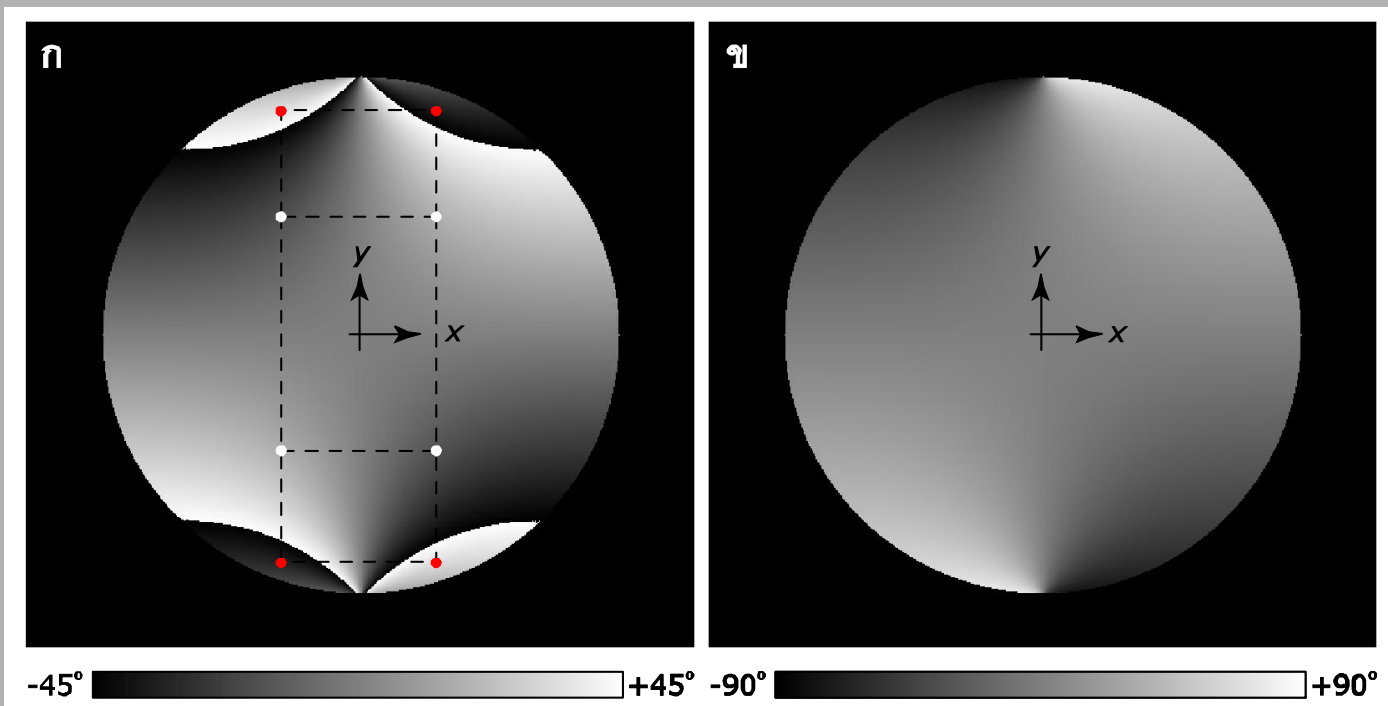

$+45^{\circ}-90^{\circ}$

$+90^{\circ}$
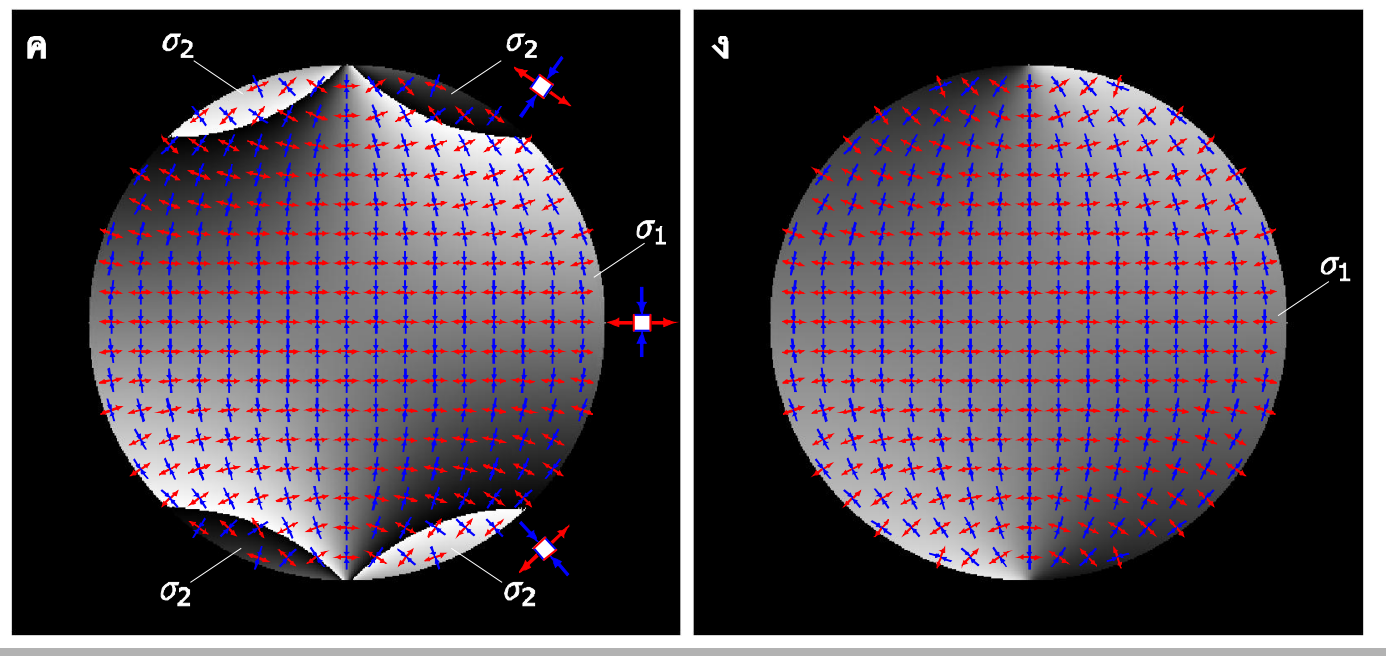

รูปที่ 7

ภาพสนามทิศทางความเค้น หลัก (ก) ย่านเฟสซ่อนรูป พร้อมด้วยจุดที่พิจารณา สำหรับตารางที่ 4 (ข) ย่าน เฟสเต็มรูป (ค) ย่านเฟสเต็ม ซ่อนรูปพร้อมด้วยลูกศร แสดงทิศทาง และ (ง) ย่าน เฟสเต็มรูปพร้อมด้วยลูกศร แสดงทิศทาง ลูกศรสีแดง และสีน้ำเงินแสดงทิศทาง ความเค้นหลัก $\sigma_{1}$ และ $\sigma_{2}$ ตามลำดับ

\section{VI. บทสรุป}

บทความนี้ได้นำเสนอวิธีการคำนวณหาทิศทาทางความเค้นหลักบนพื้นฐานของ 3 วิธี คือ วิธีสมการแปลงความ เค้น วิธีวงกลมมอร์และจุดขั้ว และค่าเจาะจงและเวกเตอร์เจาะจง นอกจากนี้บทความยังได้แสดงให้เห็นถึง ความแตกต่างระหว่างการวิเคราะห์ทิศทางความเค้นหลักเชิงจุดและเชิงสนามที่ซึ่งเป็นรากฐานสำคัญในการ เรียนในรายวิชากลศาสตร์วัสดุและรายวิชาอื่น ๆ ในระดับสูงถัดไป ผลจาการประยุกต์ใช้วิธีการดังกล่าวกับ ปัญหาแผ่นจานกลมรับแรงเข้มกดในแนวเส้นผ่านศูนย์กลาง ทำให้เราได้เห็นศักยภาพและข้อจำกัดต่าง ๆ ของ แต่ละวิธีการ

สมการแปลงความเค้นทำให้เราได้ค่าเชิงตัวเลขของทิศทางความเค้นหลักที่มีความถูกต้องสูงแต่ค่าทิศทาง ความเค้นหลักที่คำนวณได้ไม่สามารถระบุได้ว่าเป็นของความเค้นหลักค่าใดเว้นแต่จะใช้การแทนค่าย้อนกลับ วิธีวงกลมมอร์และจุดขั้วเป็นวิธีหนึ่งที่ทำให้เราเห็นพฤติกรรมของสมการแปลงความเค้นในเชิงของรูปภาพ ซึ่งทำ ให้ง่ายต่อการทำความเข้าใจ อย่างไรก็ตามผลลัพธ์ที่ได้จากวงกลมอร์จะมีค่าผิดพลาดเกิดขึ้นเสมออัน เนื่องมาจากขนาดของมาตราส่วนระหว่างค่าความเค้นและความยาวที่ใช้ในการวาด การใช้วิธีจุดขั้วทำให้เราได้ ค่าทิศทางความเค้นหลักได้ง่ายขึ้นอีกระดับหนึ่งเนื่องด้วยผู้วิเคราะห์ไม่จำเป็นต้องระมัดระวังเกี่ยวกับความ แตกต่างของมุมในวงกลมมอร์กับมุมเอลิเมนต์ความเค้นเหมือนกับสมการแปลงความเค้น สำหรับวิธีค่าเจาะจง และเวกเตอร์เจาะจงนั้นจะให้ค่าทิศทางความเค้นหลักด้วยหลักการที่ไม่ยุ่งยากซับซ้อน นอกจากนี้หลักการของ วิธีนี้สามารถช่วยให้ผู้อ่านทำความเข้าใจปัญหา 3 มิติได้ง่ายยิ่งขึ้น 
โดยหลักการแล้ว วิธีการทั้งสามข้างต้นเป็นวิธีการที่ใช้คำนวณเชิงจุด แต่ในความเป็นจริง ความเค้นและทิศทาง จะมีการแปรเปลี่ยนไปตามตำแหน่งพิกัด $x, y$ หรือพิกัดอื่นใดที่เหมาะสม ดังนั้น หากเราต้องการทราบค่าความ เค้นและทิศทางทั่วทั้งสนาม เราก็จะต้องทำการคำนวณหลาย ๆ ครั้ง ซึ่งหากพิจารณารูปที่ 7 ค หรือ 7 ง ก็จะเห็น ได้ว่า เราจะต้องคำนวณถึง 121000 ครั้ง เพื่อให้ครบทุก ๆ จุดภาพ พึงระลึกไว้ว่า จำนวนครั้งในการคำนวณที่ กล่าวถึงนี้เป็นจำนวนครั้งของการประยุกต์ใช้วิธีใดวิธีหนึ่งเท่านั้น จำนวนครั้งในการคำนวณจริงก็คือ จำนวนครั้ง ในการประยุกต์ใช้วิธีการคูณกับจำนวนครั้งของขั้นตอนการคำนวณภายในของแต่ละวิธี ซึ่งในทางปฏิบัติไม่ สามารถกระทำได้นอกจากการใช้เครื่องคอมพิวเตอร์ ความต้องการอันนี้สงผลให้เกิดวิธีการคำนวณเชิงเลข เช่น ผลต่างสืบเนื่อง และไฟไนต์เอลิเมนต์ ขึ้นมา อย่างไรก็ตาม หากเราใช้วิธีไฟไนต์เอลิเมนต์แล้วเราจะทราบได้ อย่างไรว่า ผลลัพธ์นั้นจะมีความถูกต้อง คำตอบก็คือ ยังไม่สามารถทราบได้และจะต้องมีการทดสอบหรือยืนยัน ผลด้วยวิธีการทดลองอื่นใดและวิธีที่นิยมใช้ก็คือ โฟโตอิลาสติกซิตี [11]

จากที่ได้กล่าวมาทั้งหมด ผู้อ่านได้เห็นภาพความเชื่อมโยงของวิธีการย่อยต่าง ๆ ผ่านการคำนวณหาค่าทิศทาง ความเค้นหลัก ข้อมูลและคำอธิบายทั้งหมดข้างต้นได้นำมาสูบทสรุปที่สำคัญในการวิเคราะห์ความเค้น กล่าวคือ วิธีการวิเคราะห์ความเค้นมีอยู่ด้วยกัน 3 วิธีหลัก กล่าวคือ วิธีเชิงวิเคราะห์ (analytical method) วิธี เชิงทดลอง (experimental method) และวิธีเชิงเลข (numerical method) วิธีการทั้งสามต่างก็เป็นส่วนเสริมซึ่ง กันและกัน เราไม่สามารถใช้วิธีการใดวิธีการหนึ่งได้เพียงลำพังและตัดสินผลลัพธ์ที่ได้มา ผู้อ่านคาดหวังว่า บทความนี้จะช่วยสร้างความกระจ่างหรือเป็นสะพานที่เชื่อมโยงวิธีการย่อยเหล่านั้นเข้าด้วยกันจนกลายเป็น ภาพใหญ่ภายใต้ชื่อ การวิเคราะห์ความเค้น ซึ่งจะช่วยให้ผู้อ่านเกิดความเข้าใจเชิงลึกและสามารถนำไปใช้ ประโยชน์ต่อไปได้ 


\section{บรรณานุกรม}

[1] พิเชษฐ์ พินิจ, ณัฐพงศ์ ภูพันเดียว และ ตติย์ สังข์งาม. "การไหลของความเค้น: การทดสอบด้วยวิธีการสร้างรอยแตกร้าวอย่างง่าย," วารสาร วิศวกรรมศาสตร์, ฉบับที่ 1 , เล่มที่ 3 , หน้า. $27-42,2552$.

[2] A.C. Ugural and S.K. Fenster, Advanced Strength and Applied Elasticity, 4th ed. New Jersey: Prentice-Hall, 2003.

[3] D.C. Ghiglia, and M.D. Pritt, Two-Dimensional Phase Unwrapping: Theory, Algorithms and Software, New York: Wiley-InterScience, 1998.

[4] พิเชษฐ์ พินิจ, “ความรู้ทั่วไปเกี่ยวกับโฟโตอิลาสติกซิตีและโฟโตอิลาสติกซิตีเชิงเลข," วิศวกรรมสาร มข., ปีที่ 36, ฉบับที่ 3, หน้า. 195-203, 2552.

[5] ศรัณยู มั่นพิศุทธิ์ และ พิเซษฐ์ พินิจ, "การจำลองสนามความเค้นของคานสี่เหลี่ยมอย่างง่ายรับแรงกระจายเอกรูปและแผ่นเรียบบางมีรูกลมตรง กลางรับความเค้นเฉือนล้วนด้วยโฟโตอีลาสติกซิตีเชิงเลข," ในการประชุมวิชาการเครือข่ายวิศวกรรมเครื่องกลแห่งประเทศไทย ครั้ง ที่ 23,2552 , บนซีดีรอม AMM-026109

[6] A.J. Durelli, E.A. Phillips, and C. H. Tsao, Introduction to the Theoretical and Experimental Analysis of Stress and Strain. New York: McGraw-Hill, 1958.

[7] S. Barone, G. Burriesci, and G. Petrucci, "Computer aided photoelasticity by an optimum phase stepping method," Experimental Mechanics, vol. 42, no. 2, pp. 132-139, 2002.

[8] P. Siegmann, D. Backman, and E. A. Patterson, "A Robust approach to demodulating and unwrapping phase-stepped photoelastic data," Experimental Mechanics, vol. 45, no. 3, pp. 278-289, 2005.

[9] P. Pinit and E. Umezaki, "Digitally whole-field analysis of isoclinic parameter in photoelasticity by four-step color phase-shifting technique," Optics and Lasers in Engineering, vol. 45, no. 7, pp. 795-807, 2007.

[10] พิเชษฐ์ พินิจ, " อิทธิพลของสนามทิศทางต่อการหาสนามความเค้นในวิธีโฟโตอิลาสติกซิตีเชิงเลขแบบใช้แสงโพลาไรซ์วงกลม," ในการประชุม วิชาการทางวิศวกรรมศาสตร์มหาวิทยาลัยสงขลานครินทร์ ครั้งที่ 7,2552 , หน้า 579-583

[11] E. Umezaki and S. Terauchi, "Extraction of isotropic points using simulated isoclinics obtained by photoelasticity-assisted finite element analysis." Opt. Laser Eng., vol. 38 No. 1-2, pp. 71-85, 2002.

[12] M.M. Frocht, Photoelasticity, Vol. 2. New York: John-Wiley \& Sons, 1948.

[13] ศรัณยู มั่นพิศุทธิ์ และ พิเชษฐ์ พินิจ, “การตรวจสอบผลเฉลยจากทฤษฎีสภาพยืดหยุ่นของแผ่นวงแหวนรับแรงเข้มกดตรงกันข้ามตามแนวเส้นผ่าน ศูนย์กลางด้วยวิธิวิเคราะห์ความเค้นในช่วงยืดหยุ่นโดยแสงเชิงดิจิตอล," ในการประชุมวิชาการเครือข่ายวิศวกรรมเครื่องกลแห่งประเทศไทย ครั้งที่ 22, 2551, บนซีดีรอม AMM-003

[14] P. Pinit, "Development of Windows-based program for analysis and visualization of two-dimensional stress field in digital photoelasticity", Songklanakarin Journal of Science and Technology, vol. 31 No. 2, pp. 205-212.

20 วารสารวิศวกรรมศาสตร์ : 